\title{
Some Aspects of the Setting and Hardening of Gypsum Plaster
}

\section{U.S.} PARTMENT OF COMMERCE National $Q C$ eau 100 of $15753^{\text {irds }}$ 0.755 973 .2 



\section{Some Aspects of the Setting and Hardening of Gypsum Plaster}

James R. Clifton

Institute for Applied Technology

National Bureau of Standards

Washington, D.C. 20234

NBS Technical Notes are designed to supplement the Bureau's regular publications program. They provide a means for making available scientific data that are of transient or limited interest. Technical Notes may be listed or referred to in the open literature.

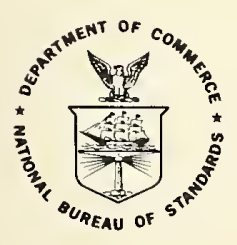

U.S. DEPARTMENT OF COMMERCE, Peter G. Peterson, Secretary NATIONAL BUREAU OF STANDARDS, Lawrence M. Kushner, Acting Director, Issued January 1973 
National Bureau of Standards Technical Note 755

Nat. Bur. Stand. (U.S.), Tech. Note 755, 33 pages (Jan. 1973) CODEN: NBTNAE

For sole by the Superintendent of Dacuments, U.S. Government Printing Office, Washington, D.C. 20402.

Price $\$ .55$ domestic postpaid or $\$ .40$ G.P.O. Bookstore. 
1. Introduction 1

2. Experimental 2

2.1 Materials 2

2.1.1 Plaster of Paris 2

2.1.2 Calcium Sulfate Hemihydrate 2

2.1.3 Other Materials 2

2.2 Hydration Studies 2

2.3 Differential Thermal Analysis 2

2.4 Scanning Electron Microscopy 2

2.5 X-ray Powder Diffraction Patterns 4

3. Experimental Results 4

3.1 Period of Setting of Gypsum Plaster 4

3.1.1 General Observations 4

3.1.2 Effects of Temperature on the Rate of Setting 4

3.1.3 Acceleration of the Set 4

3.1.4 Retardation of the Set $\quad 8$

3.1.5 Hydration Rate of Gypsum Plaster $\quad 8$

3.2 Differential Thermal Analysis of Set Gypsum Plasters 15

3.3 Scanning Electron Micrographs of Set Gypsum Plasters 15

3.4 X-ray Powder Diffraction Patterns of Set Gypsum Plasters 21

4. Discussion 21

4.1 Setting and Hardening Mechanism of Gypsum Plaster 21

4.2 Kinetic Relationships 22

4.3 Variations in the Setting and Hardening Rates of Gypsum Plasters 24

5. Sunmary and Conclusions 27

6. Acknowledgment 27

7. References 28 

Some Aspects of the Setting and Hardening of Gypsum Plaster

James R. Clifton

The mechanism by which gypsum plaster sets and hardens has been investigated and the results generally are consistent with the crystallization theory. No evidence for the presence of colloidal intermediates has been found. The crystallization theory is modified to include, as an intermediate species, solvated calcium sulfate hemihydrate molecules. Evidence is presented that supports the belief that more than one reaction is responsible for the setting and hardening of gypsum plaster.

The roles of accelerators and retarders have been studied by calorimetric, differential thermal analysis, and scanning electron microscopic techniques. The cation is more effective than the anion in accelerating the setting and hardening of gypsum plasters; the catalytic order follows the sequence $M^{+}>\mathrm{M}^{2+}>\mathrm{M}^{3+}$. Small amounts of retarders can severely retard the setting and hardening processes.

Influences of temperature, impurities, and production conditions on the setting rates of gypsum plasters are discussed.

Keywords: Colloidal theory; crystallization theory; gypsum; hydration; induction period; plaster of paris; setting mechanisms.

\section{Int roduction}

The setting and hardening of gypsum plaster is attributed to the hydration of plaster of paris $\left(\mathrm{CaSO}_{4} \cdot \mathrm{I} / 2 \mathrm{H}_{2} \mathrm{O}\right)$ to calcium sulfate dihydrate $\left(\mathrm{CaSO} \cdot 2 \mathrm{H}_{2} \mathrm{O}\right.$ ), followed by the growth of interlocking gypsum crystals. The mechanism by which the setting and hardening takes place is still a controversial subject despite numerous studies. Gradually, two theories have evolved to explain the mechanism; the crystallization theory and the colloidal theory. These theories have been well elucidated elsewhere [1-5] and will only be briefly discussed here. In the crystallization theory, the plaster of paris dissolves to form a solution highly supersaturated with respect to calcium sulfate dihydrate. Then gypsum crystallizes from solution as interlocking rod-like crystals. In the colloidal theory, intermediate colloidal products are produced which subsequently form gypsum crystals. This crystallization of gypsum leads to the final setting and hardening. Hansen [6] has proposed a modified colloidal theory in which the first step is the hydration in situ of the plaster of paris to form a surface product akin to gypsum.

The results from studies of accelerators and retarders on the setting rate of gypsum plaster, and the results of differential thermal analysis studies are cited as supporting evidence for the colloidal theory. It has been reported [7-8] that the addition of small amounts of cations accelerates the set by increasing lyosorption and gelation. This acceleration effect increases with increasing valency of the cation. Fischer [2] has measured the differential thermograms of setting plaster at various setting ages and attributed an abnormal endothermic effect found near $100^{\circ} \mathrm{C}$ to the presence of colloidal products.

The crystallization theory has many supporters [1, 3, 10] who believe that accelerators and set retarders primarily affect the density of effective nuclei in solution. Ridge [9] and Schiller [10] have formulated kinetic equations based on crystallization phenomena that are claimed to be consistent with the setting rates.

An aspect of the setting of gypsum plaster that is not well understood is the inconsistencies of setting rates. There is usually little agreement in the setting rates of plasters from different sources. Even samples from the same source of a given plaster can give incongruous values. Furthermore, the reactivity of a given plaster may change during storage.

The purpose of the present study is threefold: (1) to determine the most reasonable mechanism that can account for the setting and hardening of gypsum plaster; (2) to ascertain the effect of set regulators on some of the properties of gypsum plasters; and (3) to investigate other factors that can perturb the reactivity of gypsum plasters. 


\section{Experimental}

\subsection{Materials}

\subsubsection{Plaster of Paris}

The plaster of paris used in this study was a comercial product made by the kettle method and designed for painters' use. The $\mathrm{CaSO}_{4} \cdot 1 / 2 \mathrm{H}_{2} 0$ content was determined to be $95 \pm 1$ percent by the methods given in ASTM Designation C 471-66. In most cases, the samples of plaster of paris were allowed to equilibrate with laboratory air at $24.5^{\circ} \mathrm{C}$ and 30 percent relative humidity for one month prior to being used.

\subsubsection{Calcium Sulfate Hemihydrate}

In this study, the term calcium sulfate hemihydrate refer's to a pure material prepared from reagent grade calcium sulfate dihydrate. The dihydrate was heated at $167^{\circ} \mathrm{C}$ for 24 hours and the product was exposed to laboratory air at 50 percent relative humidity for 48 hours. The final product contained the stoichiometric amount of water $(6.62 \%)$ for $\mathrm{CaSO}_{4} \cdot 1 / 2 \mathrm{H}_{2} \mathrm{O}$. The water cortent was determined in accordance with ASTM Designation C $471-66$.

\subsubsection{Other Materials}

All other materials used in this study were of reagent grade.

\subsection{Hydration Studies}

The hydration of plaster of paris was followed by measuring the temperature rise of mixtures of water and plaster as a function of time. A $255 \mathrm{~cm}^{3}$ glass Dewar flask fitted with a one hole cork stopper, through which extended a thermometer (with smallest graduations of $0.1{ }^{\circ} \mathrm{C}$ ), served as the calorimeter. Sixty milliliters of water at $25^{\circ} \mathrm{C}$ were placed in the Dewar and, if used, the set retarder or the set accelerator was either dissolved or thoroughly mixed with the water. Then $100 \mathrm{~g}$ of plaster of paris was transferred to the Dewar and the mixture was stirred for one half minute using a metal spatula. Most of the work was carried out in a constant temperature room at $24.5^{\circ} \mathrm{C}$ with a 30 percent relative humidity. When a run was completed, the set gypsum was removed from the Dewar by adding sufficient concentrated $\mathrm{H}_{2} \mathrm{SO}_{4}$ to cover the plaster. After about 48 hours a soft mass was formed that was easily washed out of the Dewar flask.

\subsection{Differential Thermal Analysis}

The differential thermal analysis curves were recorded using a DuPont Model 900 DTA instrument ${ }^{1}$ equipped with a micro-sample reference cell. The reference material was anhydrous reagent grade $\mathrm{Al}_{2} \mathrm{O}_{3}$ heated to $400^{\circ} \mathrm{C}$ for an hour and stored in a vacuum dessicator over phosphorus ( $V$ ) oxide until used. The reference material treated in this manner gave a flat DTA curve with glass beads in the sample compartment. Temperature measurements were made with chromel alumel thermocouples, using a reference junction temperature of $0^{\circ} \mathrm{C}$, and are accurate to within $\pm 2{ }^{\circ} \mathrm{C}$. The thermocouples were calibrated using benzoic acid (National Bureau of Standards, Standard Reference Material No. 350). Heating rates between 12 to $20^{\circ} \mathrm{C} /$ minute were used.

\subsection{Scanning Electron Microscopy}

Scanning electron micrographs were taken using a Cambridge Stereo Scan scanning electron microscope. 1 The specimens were coated with a thin deposit of gold-palladium to reduce charge accumulation. Magnification ratios were 200-10,000。

1 Certain instruments are identified in this paper in order to adequately specify the experimental conditions. In no case does such identification imply recommendation or endorsement by the National Bureau of Standards, nor does it imply that the instruments are necessarily the best available for the purpose. 


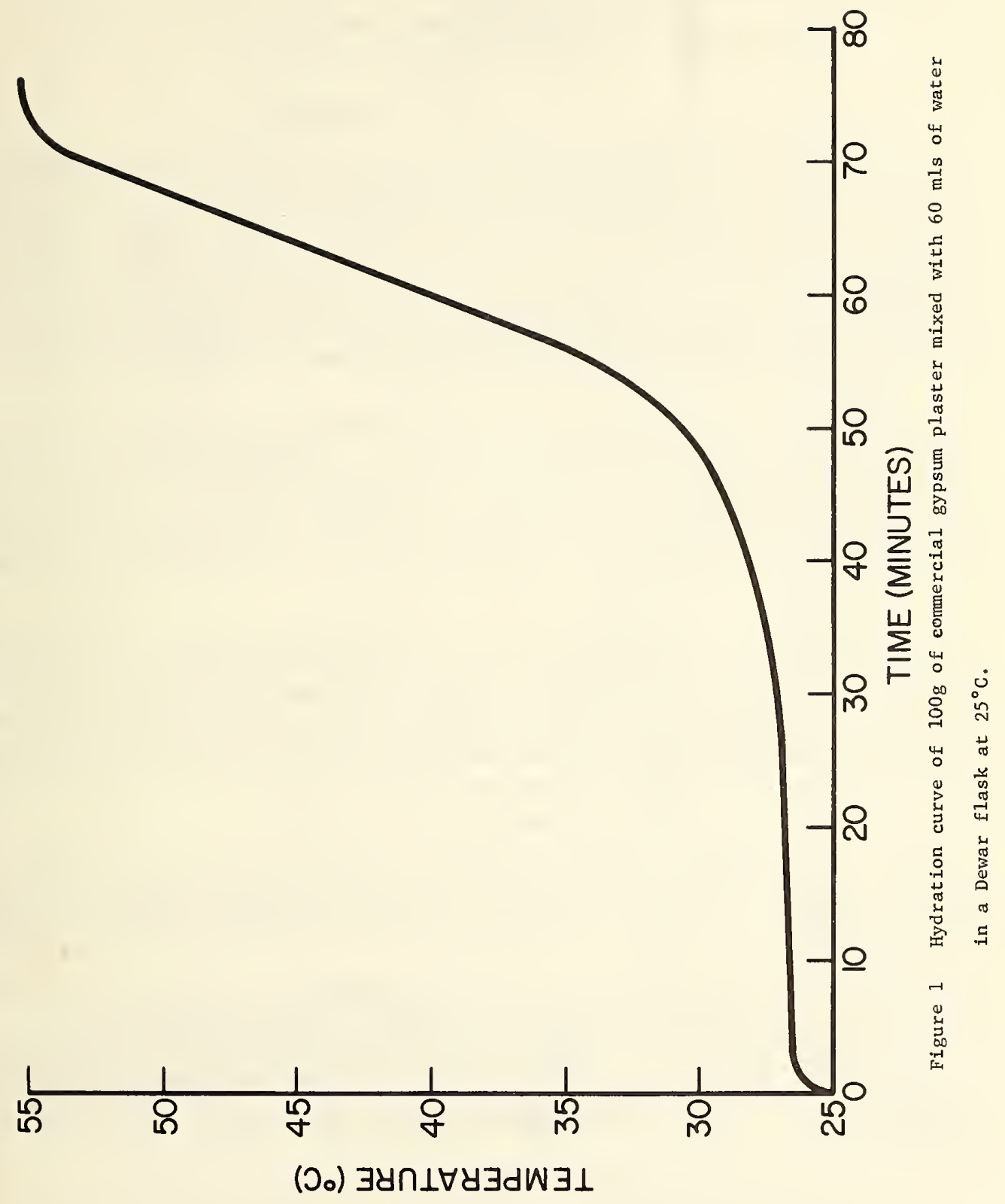




\subsection{X-ray Powder Diffraction Patterns}

The $\mathrm{x}$-ray powder diffraction patterns were obtained using unfiltered Copper $\mathrm{K}_{2}$ radiation.

\section{Experimental Results}

\subsection{Period of Setting of Gypsum Plaster}

\subsubsection{General Observations}

The setting of gypsum plaster was monitored by measuring the increase in temperature of the paste. Initial and final set times were taken to be the same as the induction period and the apparent time of complete hydration, respectively. The induction period was defined as the elapsed time required for the rate of temperature increase to exceed $0.1^{\circ} \mathrm{C} / \mathrm{minute}$ for a mixture of 100 of plaster and a selected amount of water. Time of apparent complete hydration was defined as the time after which no further increase in temperature of the system was observed. It has been reported [11] that the initial set time determined by the Gilmore needle method runs parallel to the induction period determined by calorimetric methods, with the induction period terminating shortly before the completion of the initial set. The initial set time determined by the knife cut method corresponds approximately with the induction period obtained by calorimetric methods [11].

A sigmoid hydration curve was obtained when the temperature of a plaster of paris water system was plotted as a function of time. This curve is reproduced in figure 1 for a paste of $60 \mathrm{ml}$ of water originally at $25^{\circ} \mathrm{C}$, mixed with $100 \mathrm{~g}$ of plaster for 30 secunds. The induction period and final set correspond to the two plateau regions in the curve. An almost immediate temperature rise of about $2^{\circ} \mathrm{C}$ took place when the plaster and water were mixed, possibly attributable to an adsorption phenomenon. The induction period was $37 \pm 1$ minutes and the final set time was $76 \pm 2$ minutes. The rate of maximum temperature rise for a one minute period was $1.6^{\circ} \mathrm{C} / \mathrm{min}$.

Pure calcium sulfate hemihydrate was the subject of a similar study. When $100 \mathrm{~g}$ of the hemihydrate were mixed with $60 \mathrm{ml}$ of water for 30 seconds, however, a very thick paste was formed preventing complete mixture. By using $70 \mathrm{ml}$ of water and mixing for one minute a more homogeneous paste was produced (a larger amount of water was needed with the pure calcium sulfate hemihydrate to obtained a mixable slurry as opposed to the commercial grade of plaster of paris because of the finer average particle size of the former). The induction period and final set times for this system were 6 and 49 minutes, respectively, and the rate of maximum temperature rise was $1.2^{\circ} \mathrm{C} / \mathrm{min}$.

\subsubsection{Effects of Temperature on the Rate of Setting}

Only a few systematic studies of the effect of temperature on the rate of setting have been reported [12-14], and the results of these studies differed considerably among the investigators. The results of the present study are in general agreement with those given by Ridge [1].

The influence of the initial temperature of the mixing water on the induction period, final set, and the maximum temperature rise per minute are shown in figure 2 for temperatures between 0 to $60^{\circ} \mathrm{C}$. Clearly, the maximum temperature rise rate is little affected by temperature. The final set curve runs fairly parallel to the induction period curve, as each curve gradually decreases from $4^{\circ}$ to $40^{\circ} \mathrm{C}$, and then again increases. This suggests that the induction period is the rate-determining step in the overall hydration of gypsum plaster. Further evidence for this conclusion will be presented in later sections.

\subsubsection{Acceleration of the Set}

A systematic study of additives that accelerated the set of gypsum was undertaken, which included using different cations and anions as well as varying the amount of the additives. Two salt systems were used, in one system the sulfate ion was the anion whereas in the other case it was the chloride ion (a single hydroxide, $\mathrm{Ca}(\mathrm{OH})_{2}$, was also used). 


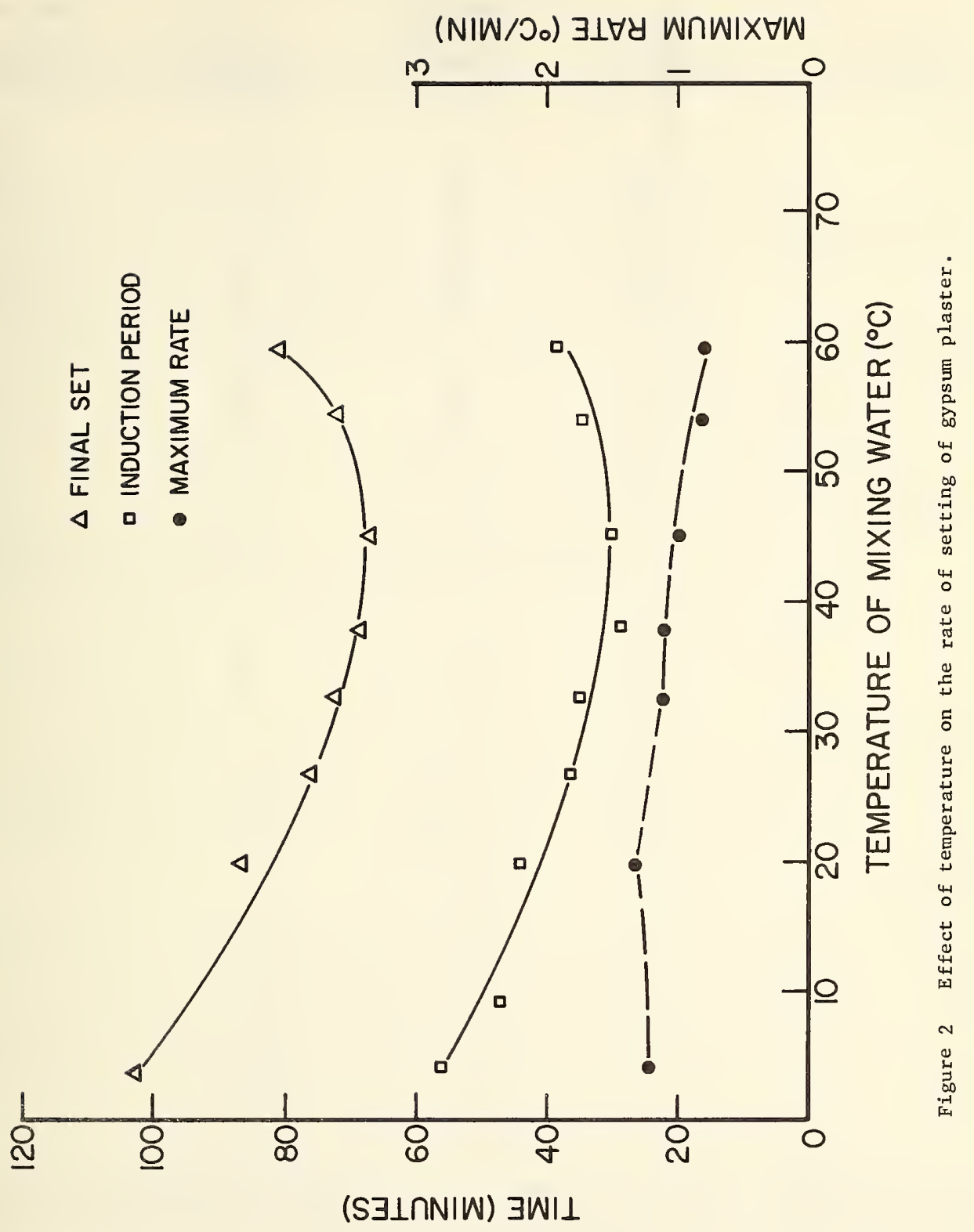




\begin{tabular}{|c|c|c|c|c|}
\hline Additive $^{a}$ & $\begin{array}{l}\text { Amount } \\
\text { (grams) }\end{array}$ & $\begin{array}{l}\text { Induction } \\
\text { Period } \\
\text { (Minutes) }\end{array}$ & $\begin{array}{l}\text { Final Set } \\
\text { (Minutes) }\end{array}$ & $\begin{array}{c}\text { Maximum } \\
\Delta \mathrm{T}^{\mathrm{b}} \\
\left({ }^{\circ} \mathrm{C} / \mathrm{min}\right)\end{array}$ \\
\hline None & & 37 & 76 & 1.6 \\
\hline Starch & $\begin{array}{l}0.5 \\
1.0 \\
2.0\end{array}$ & $\begin{array}{l}35 \\
29 \\
29\end{array}$ & $\begin{array}{l}72 \\
68 \\
74\end{array}$ & $\begin{array}{c}1.4 \\
1.4 \\
-\end{array}$ \\
\hline $\mathrm{Al}_{2}\left(\mathrm{SO}_{4}\right)_{3} \cdot 18 \mathrm{H}_{2} \mathrm{O}$ & $\begin{array}{l}0.8 \\
1.7 \\
3.3 \\
6.7\end{array}$ & $\begin{array}{l}46 \\
25 \\
22 \\
11\end{array}$ & $\begin{array}{l}87 \\
60 \\
55 \\
40\end{array}$ & $\begin{array}{l}1.2 \\
1.8 \\
1.9 \\
2.2\end{array}$ \\
\hline $\mathrm{Na}_{2} \mathrm{SO}_{4}$ & $\begin{array}{l}0.2 \\
0.4 \\
0.7 \\
1.4 \\
2.8\end{array}$ & $\begin{array}{r}21 \\
10 \\
7 \\
3 \\
3\end{array}$ & $\begin{array}{l}44 \\
33 \\
26 \\
18 \\
17\end{array}$ & $\begin{array}{l}2.3 \\
3.2 \\
3.8 \\
6.2 \\
6.0\end{array}$ \\
\hline$\left(\mathrm{NH}_{4}\right)_{2} \mathrm{SO}_{4}$ & $\begin{array}{l}0.3 \\
0.7 \\
1.0 \\
1.3 \\
2.0\end{array}$ & $\begin{array}{r}14 \\
6 \\
2 \\
1 \\
1\end{array}$ & $\begin{array}{l}41 \\
26 \\
17 \\
16 \\
12\end{array}$ & $\begin{array}{l}2.2 \\
4.2 \\
5.3 \\
6.9 \\
9.2\end{array}$ \\
\hline $\mathrm{CuSO}_{4}$ & $\begin{array}{l}0.8 \\
1.6 \\
3.2\end{array}$ & $\begin{array}{r}27 \\
14 \\
9\end{array}$ & $\begin{array}{l}63 \\
43 \\
33\end{array}$ & $\begin{array}{l}1.4 \\
2.0 \\
2.3\end{array}$ \\
\hline $\mathrm{CaSO}_{4} \cdot 2 \mathrm{H}_{2} \mathrm{O}$ & $\begin{array}{l}1.0 \\
3.0\end{array}$ & ${ }_{\text {N.I. }}^{18}$ & $\begin{array}{l}49 \\
39\end{array}$ & $\begin{array}{l}1.8 \\
1.7\end{array}$ \\
\hline $\mathrm{K}_{2} \mathrm{SO}_{4}$ & $\begin{array}{r}.5 \\
1.0 \\
2.0\end{array}$ & $\begin{array}{l}7 \\
\text { N.I. c } \\
\text { N.I. }\end{array}$ & $\begin{array}{r}28 \\
14 \\
9\end{array}$ & $\begin{array}{r}5.1 \\
6.8 \\
11.6\end{array}$ \\
\hline $\mathrm{Ca}(\mathrm{OH})_{2}$ & $\begin{array}{l}0.4 \\
1.0\end{array}$ & $\begin{array}{l}30 \\
23\end{array}$ & $\begin{array}{l}65 \\
58\end{array}$ & $\begin{array}{l}1.3 \\
1.8\end{array}$ \\
\hline $\mathrm{NaCl}$ & 1.0 & 12 & 30 & 4.0 \\
\hline $\mathrm{KC} 1$ & $\begin{array}{l}1.0 \\
1.3\end{array}$ & $\begin{array}{l}4 \\
4\end{array}$ & $\begin{array}{l}19 \\
18\end{array}$ & $\begin{array}{l}5.4 \\
5.8\end{array}$ \\
\hline $\mathrm{CaCl}_{2}$ & 2.0 & 34 & 56 & 1.8 \\
\hline Sulfur & 0.5 & 32 & 64 & 1.7 \\
\hline
\end{tabular}

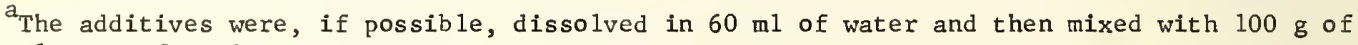
plaster of paris.

${ }^{b}$ Maximum temperature rise in ${ }^{\circ} \mathrm{C}$ for a one minute interval.

cNo apparent induction period. 
Table 2. Effect of Retarders on the

Setting Rates of Gypsum Plaster

\begin{tabular}{|c|c|c|c|c|}
\hline Additive $^{a}$ & $\begin{array}{l}\text { Amount } \\
\text { (grams) }\end{array}$ & $\begin{array}{c}\text { Induction } \\
\text { Period } \\
\text { (Minutes) }\end{array}$ & $\begin{array}{l}\text { Final Set } \\
\text { (Minutes) }\end{array}$ & $\begin{array}{l}\text { Maximum } \\
\left({ }^{\circ} \mathrm{C} / \mathrm{min}\right)\end{array}$ \\
\hline $\mathrm{NaC}_{2} \mathrm{H}_{3} \mathrm{O}_{2}$ & 1.7 & 60 & 110 & - \\
\hline $\mathrm{NH}_{4} \mathrm{C}_{2} \mathrm{H}_{3} \mathrm{O}_{2}$ & 0.8 & 70 & 118 & 1.1 \\
\hline $\mathrm{Na}_{2} \mathrm{~B}_{4}{ }^{0} \cdot{ }^{\cdot 10 \mathrm{H}_{2} \mathrm{O}}$ & 0.8 & 178 & 218 & - \\
\hline Succinic Acid & 0.2 & 213 & 271 & 0.5 \\
\hline Tartaric Acld & 0.2 & 61 & 106 & 1.0 \\
\hline Gelatin & 0.1 & - & 240 & - \\
\hline
\end{tabular}

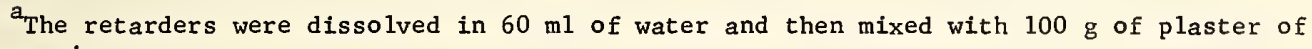
paris.

${ }^{b}$ Maximum temperature $\mathrm{rise}$ in ${ }^{\circ} \mathrm{C}$ for a one minute interval. 
The results of this study are listed in table 1 .

Two classes of accelerators were observed (based on equimolar additions): those that primarily shortened the induction period and the final set, and those that both shortened the induction period and the flnal set and also substantially increased the maximum temperature rise rate. Salts of cations belonging to periodic groups II and III were examples of accelerators that primarily decreased the setting times. Salts of the alkali group were found to increase the maximum temperature rise rate and to reduce the hydration period.

A comparison of the catalytic effect of cations on the setting rates of gypsum plaster provides several interesting relations. The order of the cations in accelerating the set of plaster is $\mathrm{K}^{+}>\mathrm{NH}_{4}^{+}>\mathrm{Na}^{+}>\mathrm{Ca}^{2+}>\mathrm{Cu}^{2+}>\mathrm{Al}^{3+}$ (based on equimolar additions). This series of decreasing activity is in close agreement with the order of increasing ionic potential, $\emptyset$ (ionic potential, $\emptyset$, is the ionic charge of the cation divided by its ionic radius). An exception is the reversal of the order of $\mathrm{K}^{+}, \emptyset$ of 0.75 , and $\mathrm{NH} t_{4}, \emptyset$ of 0.71 ; but the difference is slight and possibly associated with comparing a polyatomic ion with an monoatomic species. The effect of increasing the amount of some sulfate salts on the induction period is shown in figure 3. At low concentration, the catalytic activity of the cations is somewhat reversed. The influence of various accelerators on the maximum temperature rise rate is shown in figure 4. Considering this rate, the catalytic order is $\mathrm{NH}_{4}^{+}>\mathrm{K}^{+}>\mathrm{Na}^{+}>\mathrm{Al}^{3+}>\mathrm{Cu}^{2+}$.

The anions did not exert as strong a catalytic effect as the cations and the observed order is $\mathrm{SO}_{4}^{2-}>\mathrm{Cl}^{-}>\mathrm{OH}^{-}$.

The effects of starch and, sulfur were slight, possibly because of their limited solubilities.

The accelerators did not alter the physical appearance of the paste or of the set plaster, except for $\mathrm{Al}_{2}\left(\mathrm{SO}_{4}\right)_{3} \cdot 18 \mathrm{H}_{2} \mathrm{O}$. When $\mathrm{Al}_{2}\left(\mathrm{SO}_{4}\right)_{3} \cdot 18 \mathrm{H}_{2} \mathrm{O}$ was used, the paste and set plaster had foamy structures in contrast to the more smooth dense structure of pure gypsur plaster.

\subsubsection{Retardation of the Set}

The results of a brief study of some additives that retarded the setting rate of gypsum plaster are presented in table 2. The strong retardation ability of succinic acid was evident, for when $0.2 \mathrm{~g}$ was used, the inducting period was extended to six and one half hours. When two grams were used, the final set was not obtained within 24 hours after mixing. The addition of $0.1 \mathrm{~g}$ of gelatin resulted in increasing the final set time to about four hours.

The major effect of the regarders on the rate of setting is to increase the induction period. It has been stated [6] that retarders probably prevent complete hydration of gypsum plaster. In the present study, the extent of hydration was determined by measuring the water of hydration using thermogravimetric methods. The results indicate that the degree of hydration taking place when using either set-retarders or accelerators is the same as with the pure plaster (in all three cases the percentage of hydration was 96 , calculated by assuming that the plaster of paris was 100 percent $\mathrm{CaSO}_{4} \cdot 1 / 2 \mathrm{H}_{2} \mathrm{O}$ ).

\subsubsection{Hydration Rate of Gypsum Plaster}

The hydration rate of gypsum plaster was determined in a crude manner by taking samples of the paste at selected times and recording their differential thermograms and scanning electron micrographs. Samples were taken at 5, 25, 40,60,80, and 120 minutes and 24 hours after mixing the plaster of paris with water. Samples removed at 5, 25, 40, and 60 minutes had their setting processes quenched by treatment with absolute ethanol. The extent of formation of gypsum in the quenched materials was detected by both differential thermal analysis methods (figure 5) and scanning electron microscopic methods (figure 6). The large crystals in figure $6 \mathrm{a}$ are those of the unhydrated plaster of paris and the small white particles (brightness due to charge accumulation) are probably either solvated hemihydrate crystals or small gypsum crystals. After 60 minutes (figures $6 \theta$ and $6 \mathrm{f}$ ), the rod-shape crystals that are characteristic of precipitated $\mathrm{CaSO}_{4} \cdot 2 \mathrm{H}_{2} \mathrm{O}$ crystals (figure 7) 


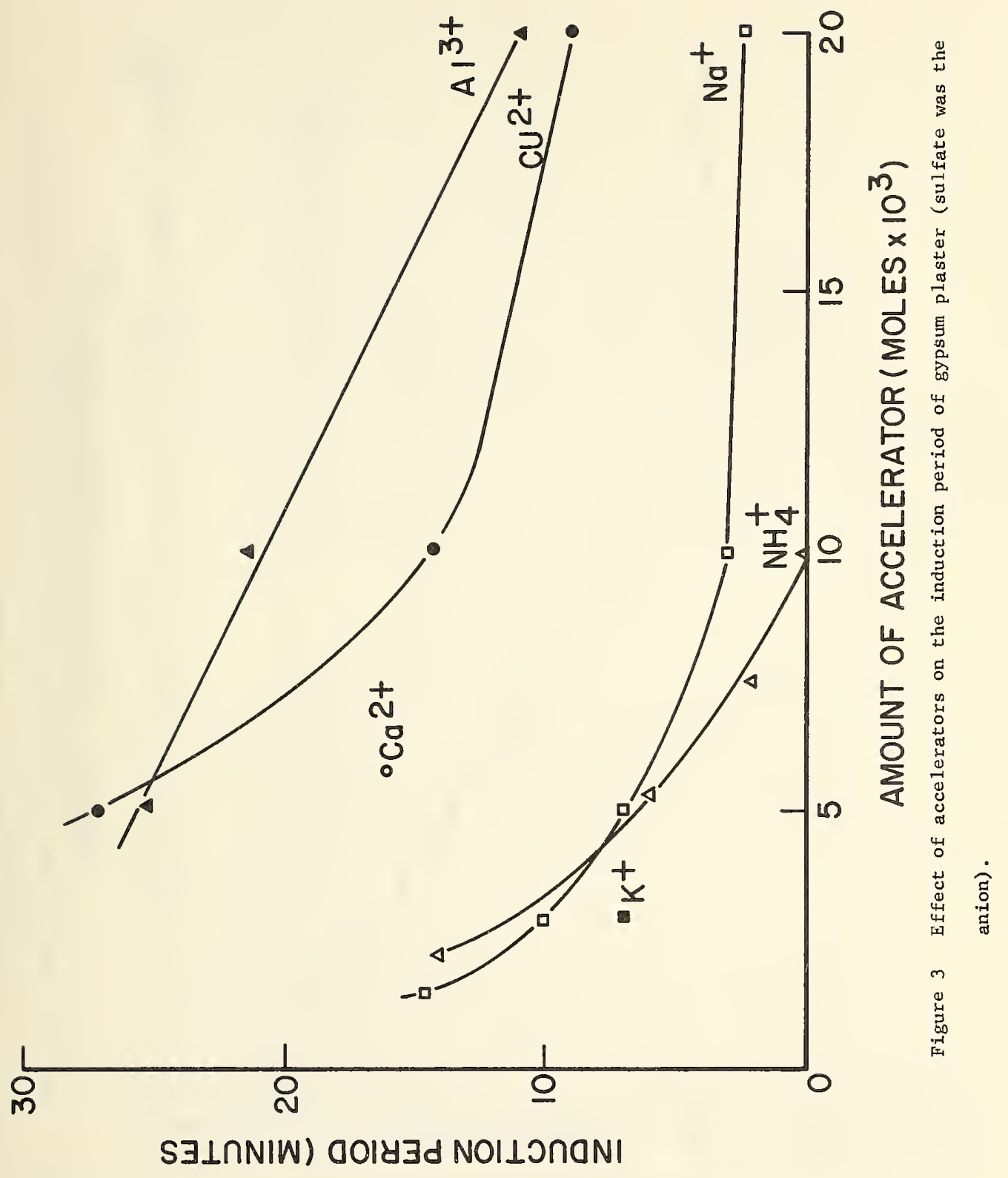




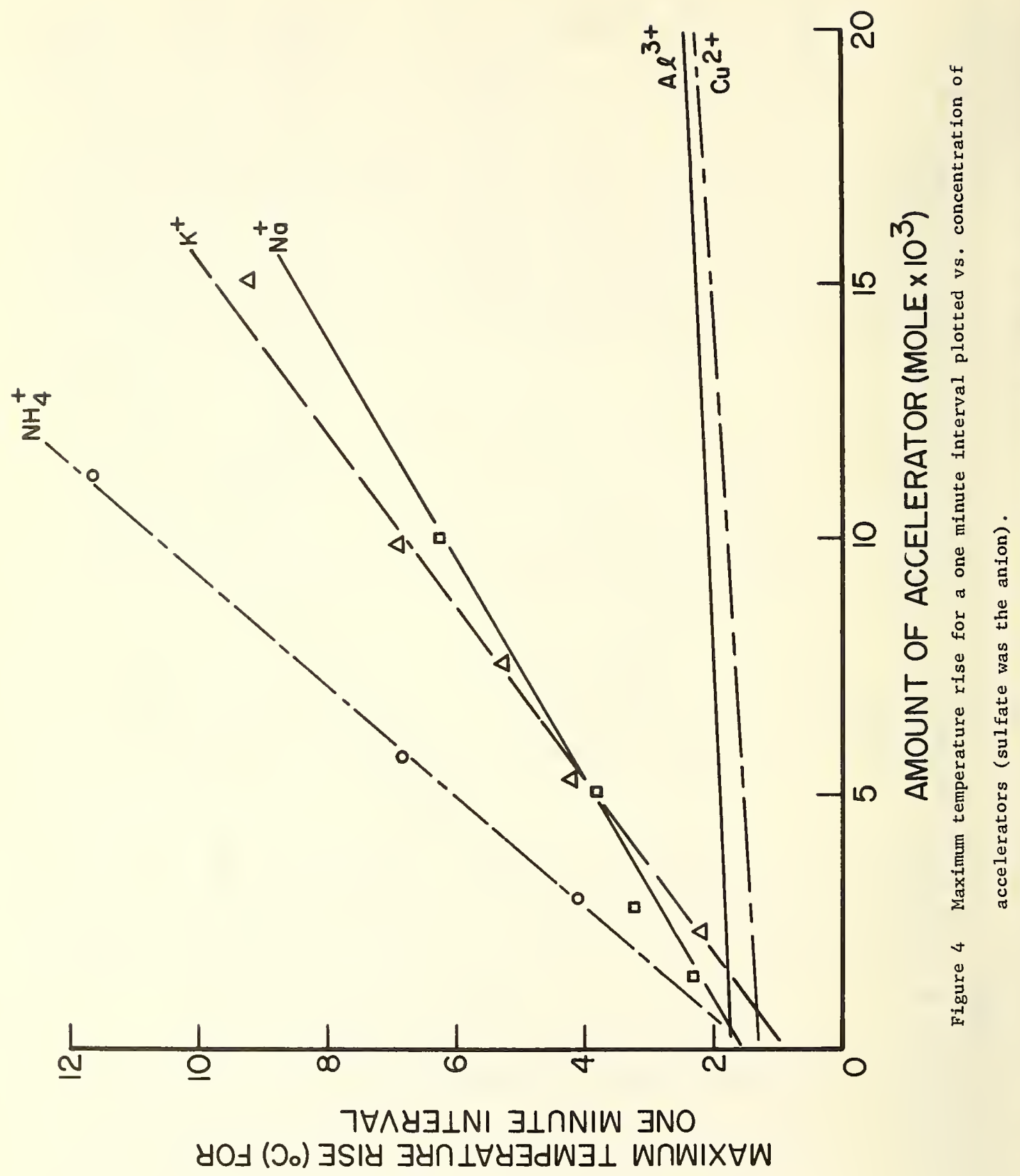




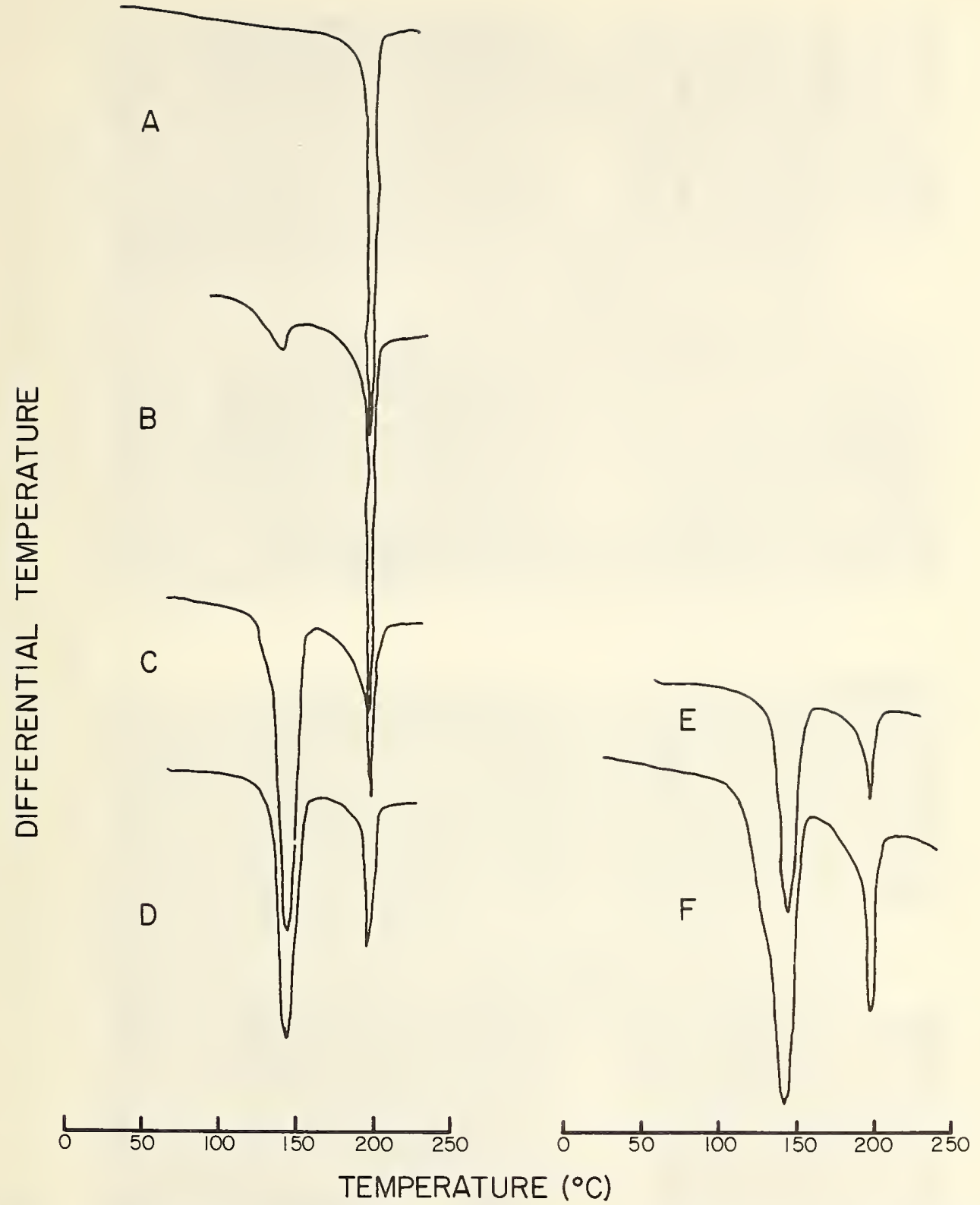

Figure 5 Differential thermograms of quenched plaster-water systems. Times after mixing were: A. 25 minutes; B, 40 minutes; C, 60 minutes; D, 80 minutes; E, 120 minutes; F, 24 hours. 

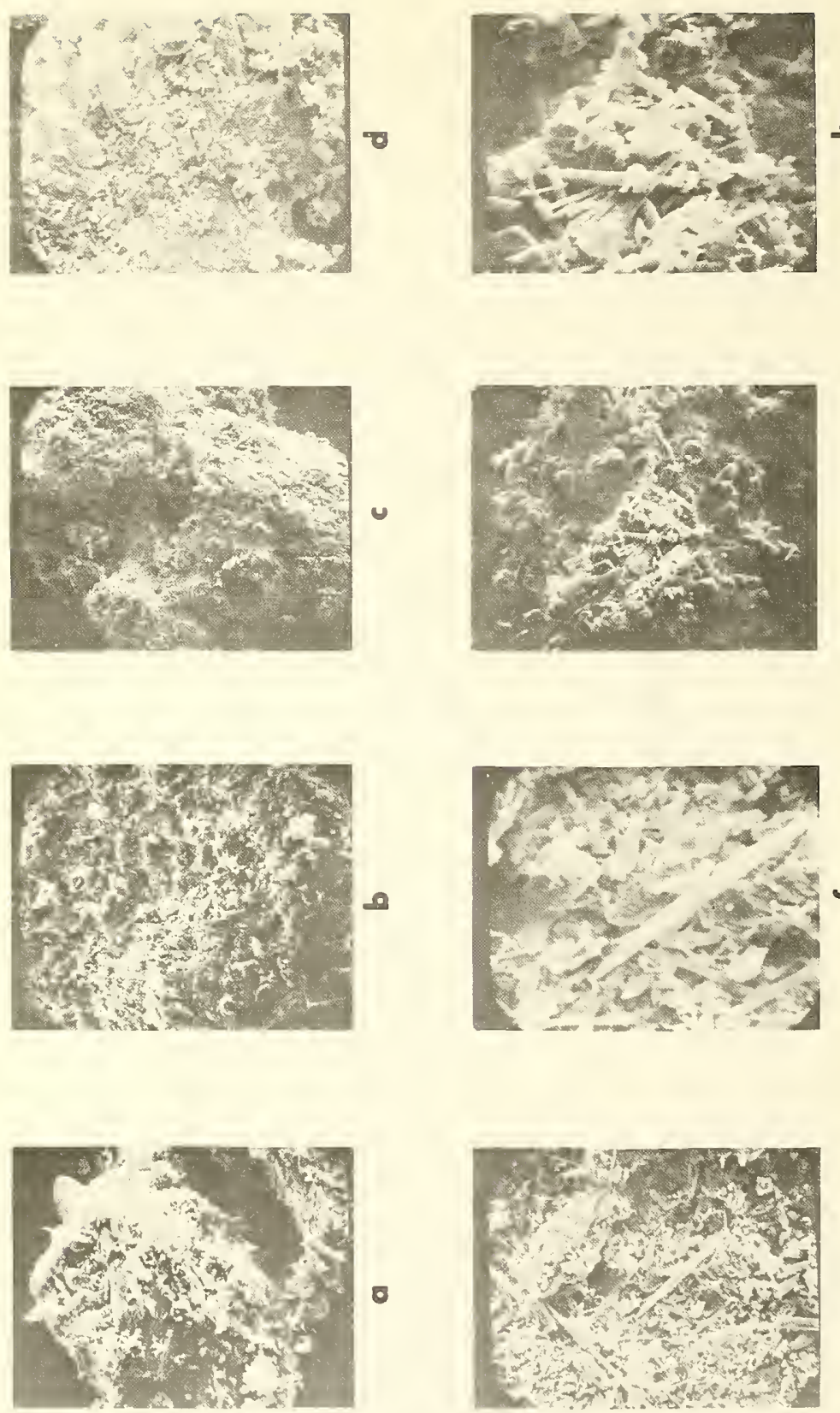

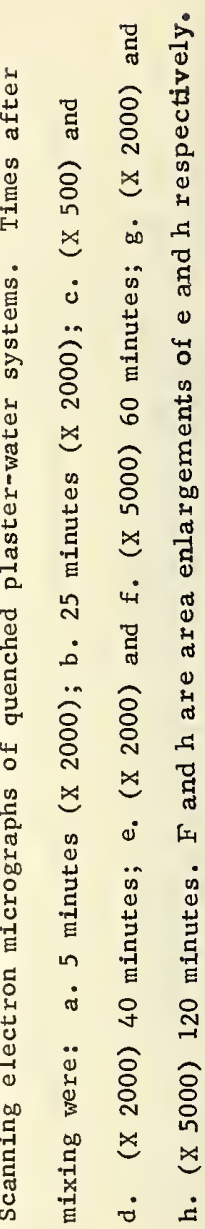

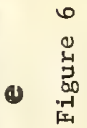



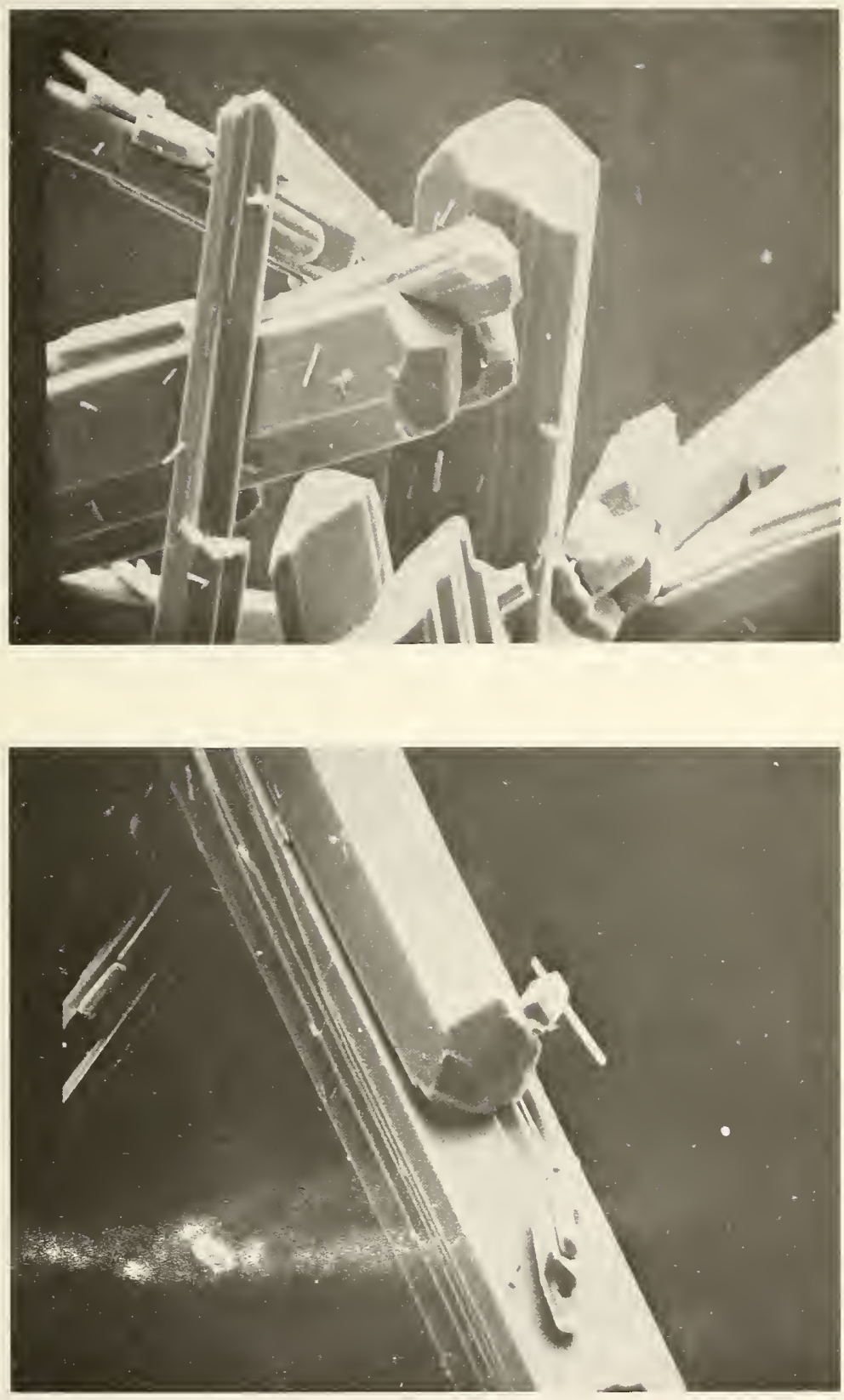

Figure 7 Scanning electron micrographs of precipitated $\mathrm{CaSO}_{4} \cdot 2 \mathrm{H}_{2} \mathrm{O}, \mathrm{X} 900$. 

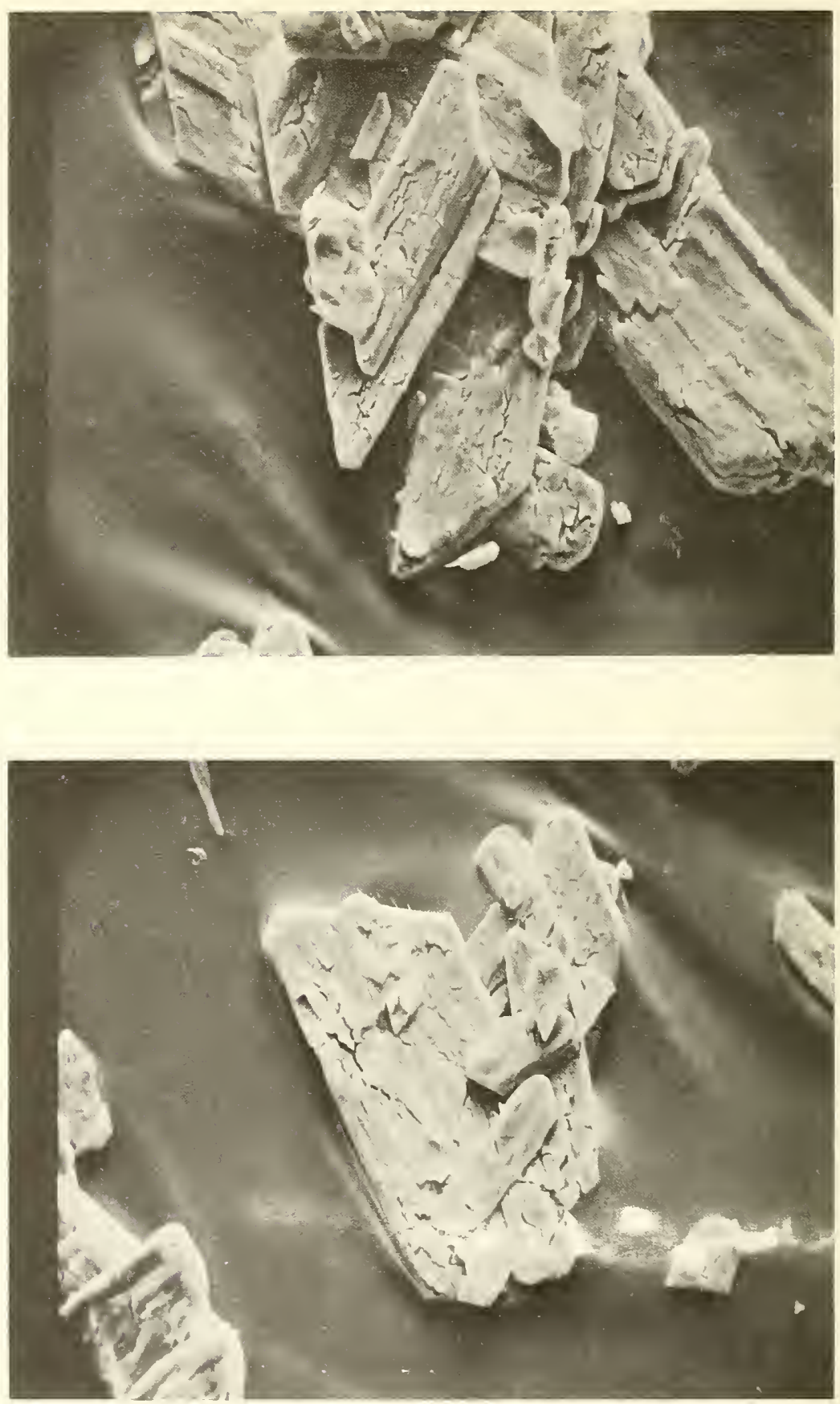

Figure 8 Scanning electron micrograph of plaster of paris, X 2000. 
are reajily apparent. After 120 minutes (figures $6 \mathrm{~g}$ and $6 \mathrm{~h}$ ), which surpasses the final set time, a few plate-like crystals are still remaining. These crystals have the same shape as authentic $\mathrm{CaSO}_{4} \cdot 1 / 2 \mathrm{H}_{2} 0$ molecules (figure 8 ). This suggests that an in situ hydration mechanism (in $\stackrel{4}{\mathrm{p}}$ lace hydration, without dissolution) has some role in the setting of gypsum plaster.

An interesting phenomenon is noted when comparing the differential thermograms for the 2 and 24 hour specimens. On the low temperature profile of the major first endothermic effect of the 24 hour specimen, are located two shoulders that were not detected with the two hour specimen (figure 5).

\subsection{Differential Thermal Analysis of Set Gypsum Plasters}

The influence of the addition of accelerators and retarders on the differential thermograms of set gypsum plaster is given in table 3 and in figure 9. A straight base line was not obtained in the differential thermograms, probably due to the evolution of adsorbed water, making it difficult to estimate the first break temperature of the endothermic effects. Therefore, only the peak temperatures, $T_{\text {peak, }}$, were measured (the peak temperature is the temperature of the apex of an endothermic or exothermic effect).

Pure set gypsum plaster (no additive) gave $\mathrm{T}$ of $151^{\circ} \mathrm{C}$ and $192^{\circ} \mathrm{C}$ compared with $150^{\circ} \mathrm{C}$ and $197^{\circ} \mathrm{C}$ for the first and second endotherms of Palcium sulfate dihydrate [15]. When either an accelerator or a retarder was added, three endothermic effects were observed in some thermograms. Of these three effects, the first endothermic effect was the smallest, sometimes being only a shoulder on the first strong endothermic effect and had $T_{\text {peak }}$ between 100 to $120^{\circ} \mathrm{C}$. The first major endothermic effect was attributed to the dehydration of gypsum plaster to plaster of paris (calcium sulfate hemihydrate), and in some cases a doublet was measured. The $\mathrm{T}$ of the first major effect, were between $127^{\circ}$ to $153^{\circ} \mathrm{C}$. The second major endothermic peakect was associated with the dehydration of plaster of paris to anhydrous calcium sulfate. Peak temperatures for this effect were between $192^{\circ} \mathrm{C}-197^{\circ} \mathrm{C}$.

The differential thermograms of the pure accelerators and retarders were recorded. In no instance did the position and shape of the endothermic curves of the pure set regulators correspond to the curves observed in the thermograms of the set gypsum plasters.

Furthermore, since the quantities of the regulators added to the plasters were small, their endothermic effects would probably be too small to be detected.

\subsection{Scanning Electron Micrographs of Set Gypsum Plasters}

Several interesting modifications were observed in the macro-crystalline structure of set gypsum plaster resulting from the addition of accelerators and retarders. The electron scanning micrographs are shown in figures 10,11 and 12 . Shown in figure 10 are the micrographs (magnification ratio 2300) for the pure plaster and plasters containing additions of $\mathrm{CuSO}_{4}, \mathrm{Na} \mathrm{B}_{4}{ }^{0} \cdot 10 \mathrm{H}_{2} \mathrm{O}$ and $\left(\mathrm{NH}_{4}\right)_{2} \mathrm{SO}_{4}{ }^{\circ}$ These four micrographs are similar to each other, with ${ }^{4}$ the crystals having basically hexagonal faces and rod-like shapes. A few plate-like crystals, the same shape as the plaster of paris crystals (figure 8), are also present, again suggesting that to a small extent the hydration of plaster of paris proceeds through a hydration in situ mechanism as well as by a dissolution mechanism. The other accelerators, with the exception of $\mathrm{Al}_{2}\left(\mathrm{SO}_{4}\right)_{3} \cdot 18 \mathrm{H}_{2} 0$, gave micrographs similar to those in figure 11 .

The scanning electron micrographs for the gypsum plasters containing $\mathrm{NH}_{4} \mathrm{C}_{2} \mathrm{H}_{3} \mathrm{O}_{2}$, succinic acid, tartaric acid, and gelatin are shown in figure 11, (magnification ratios 550 to 2000). These four additives are all retarders and small amounts as listed in table 2 were used. The addition of retarders, with the exception of $\mathrm{NaB}_{4} 0_{7} \cdot 10 \mathrm{H}_{2} 0$, promoted the growth of much larger crystals than those observed for the pure plaster? The largest growth was in the cross section plane perpendicular to the mainfold rotation axis of the hexagonal rods.

${ }^{2}$ Set gypsum plaster denotes the hydration product of plaster of paris. The product was air dried for 24 hours before being tested. 
Table 3. Peak Temperatures of Endothermic Curves of Set Gypsum Plaster Peak Temperatures $\left({ }^{\circ} \mathrm{C}\right)$

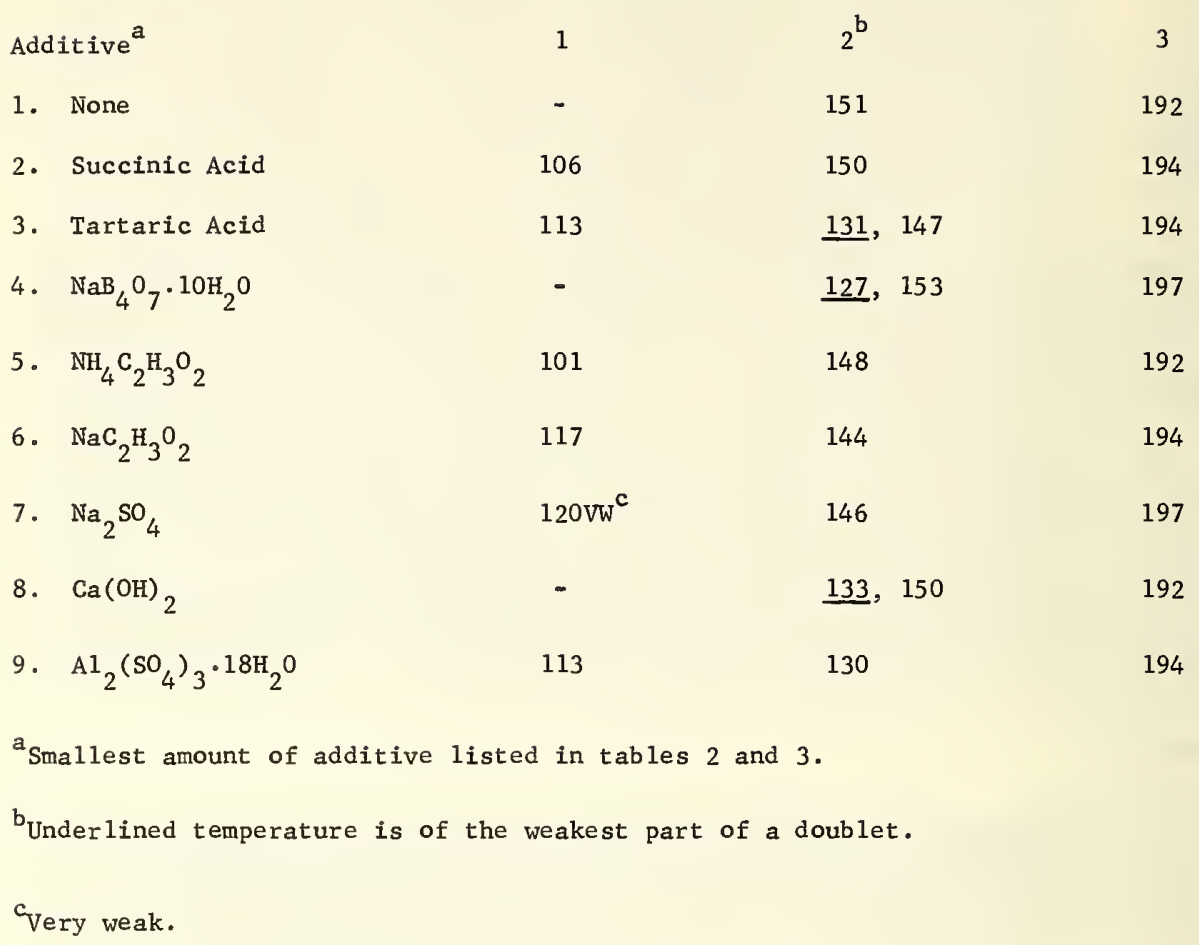




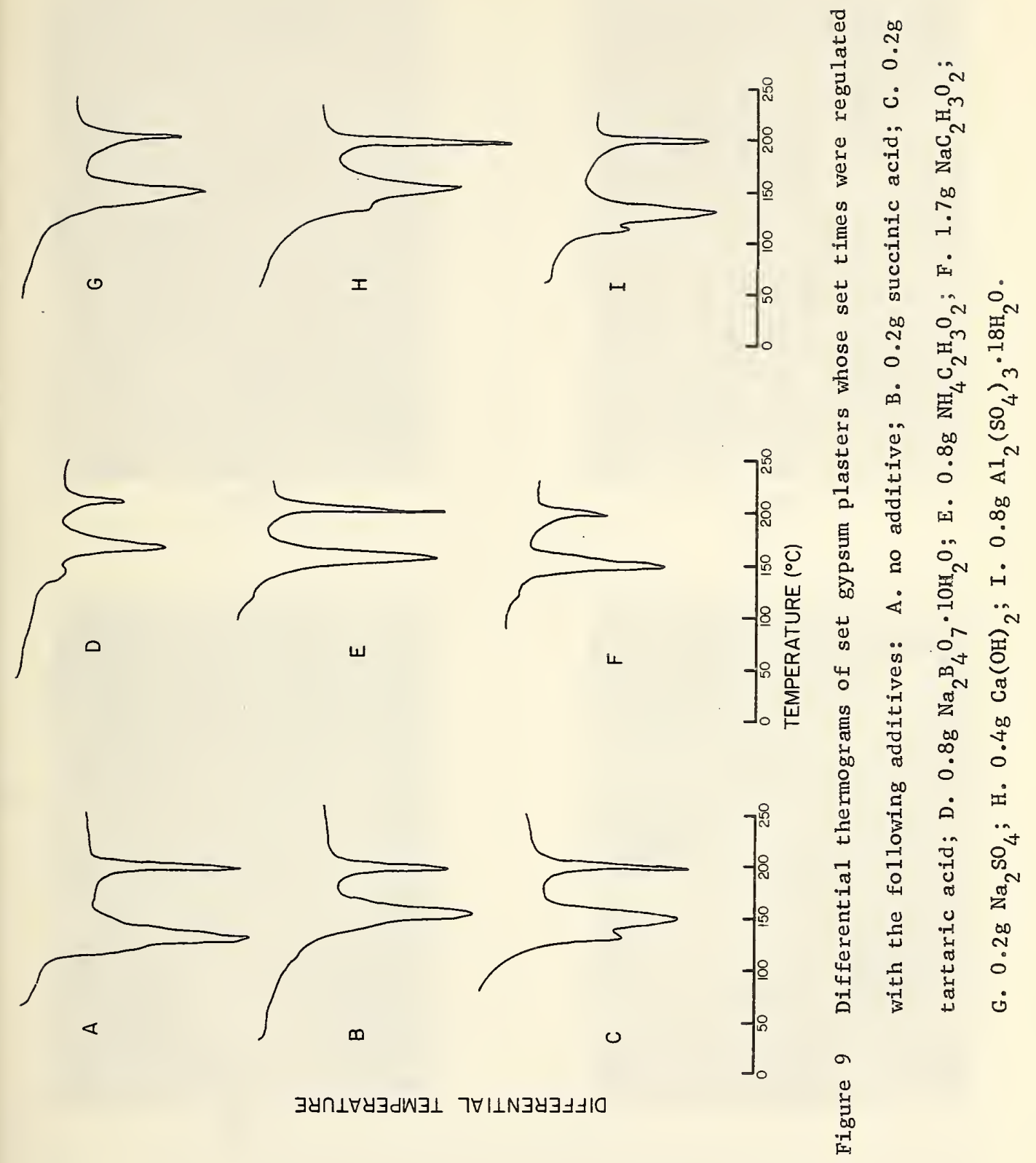




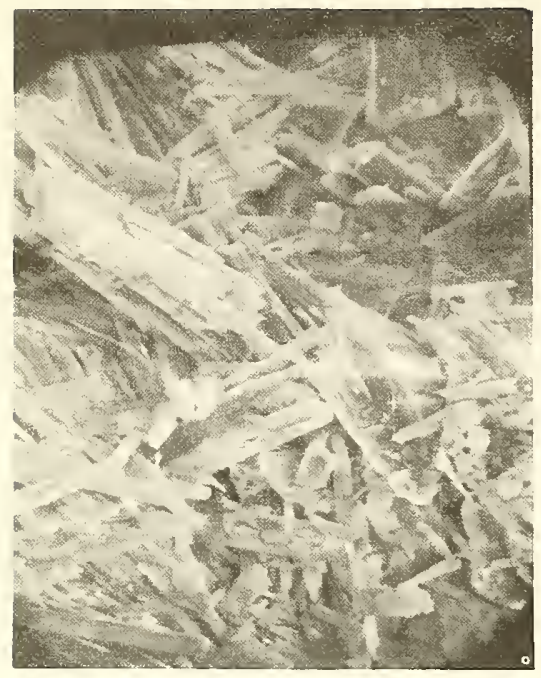

6

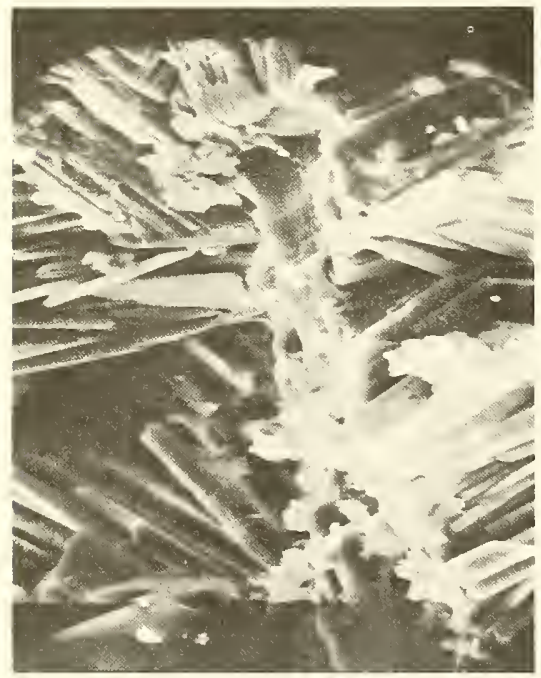

G

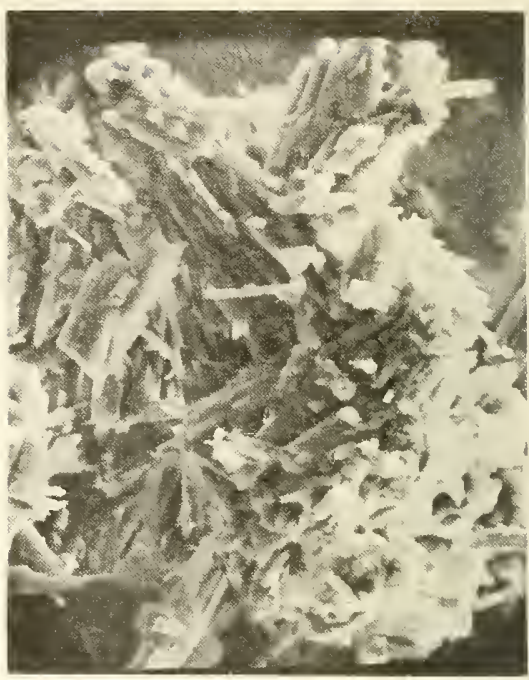

b

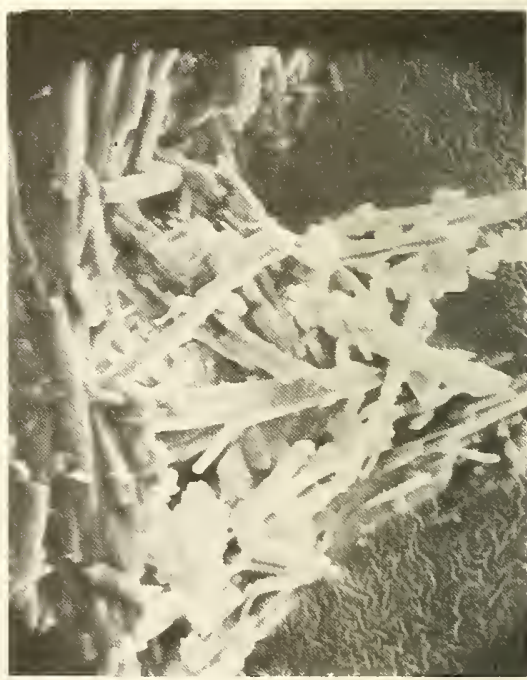

d

Figure 10 Scanning electron micrographs of set gypsum plasters with (X 2300): a. no additive; b. $0.8 \mathrm{~g} \mathrm{CuSO}_{4}$; c. $0.8 \mathrm{~g} \mathrm{Na} 2_{4}{ }^{0} 7^{\cdot} \cdot 10 \mathrm{H}_{2} 0$; d. $0.7 \mathrm{~g}\left(\mathrm{NH}_{4}\right)_{2} \mathrm{SO}_{4} \cdot$ 


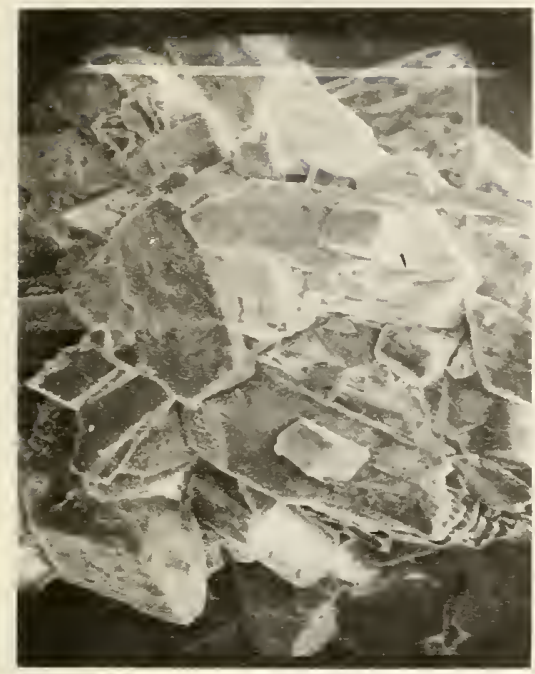

c

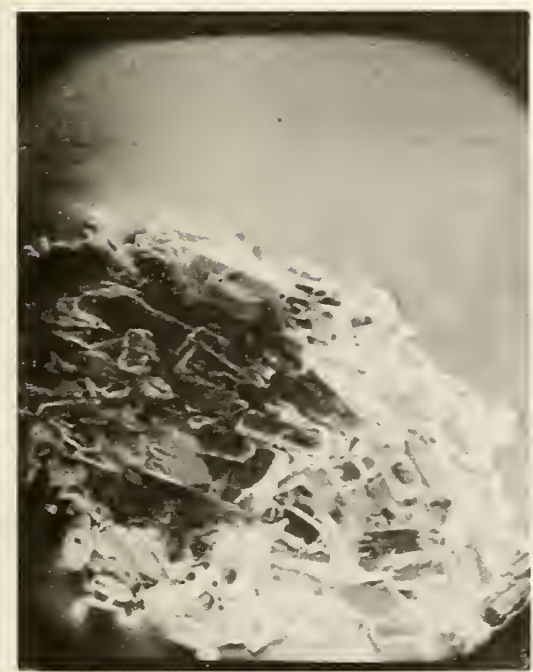

c

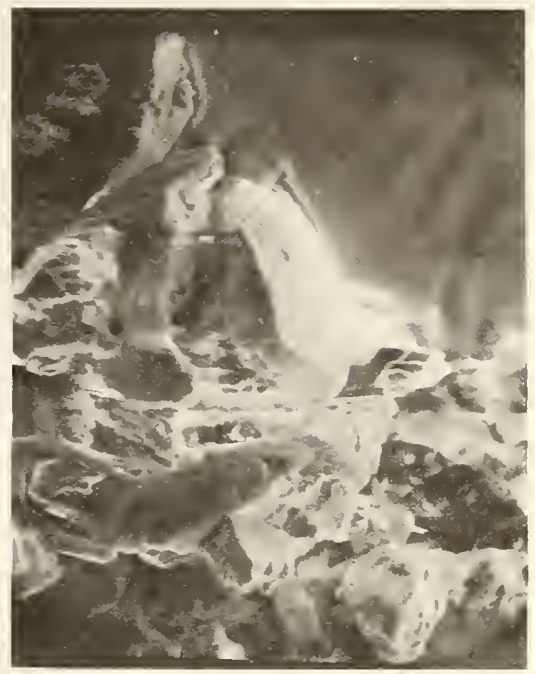

b

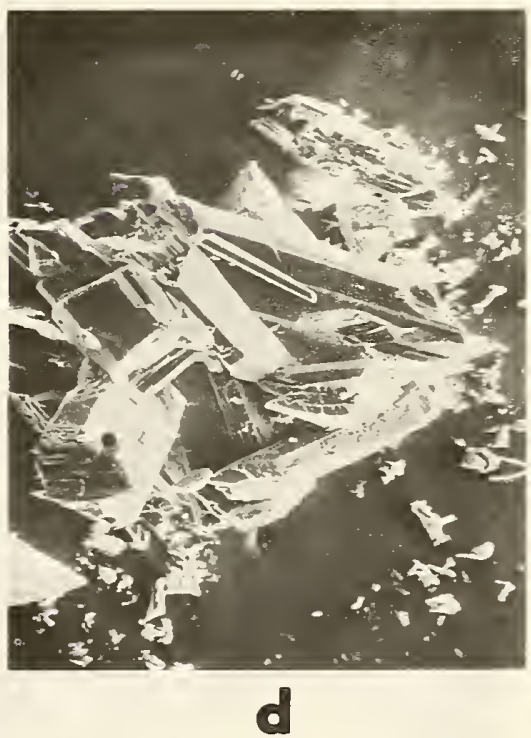

Figure 11 Scanning electron micrographs of set gypsum plasters with: a. $0.8 \mathrm{~g} \mathrm{NH} \mathrm{C}_{2} \mathrm{H}_{3} \mathrm{O}_{2}$ (X 1100); b. 0.2g succinic acid (X 1330); c. 0.2g tartaric acid (X 2600) d. $0.1 g$ gelatin (X 500). 

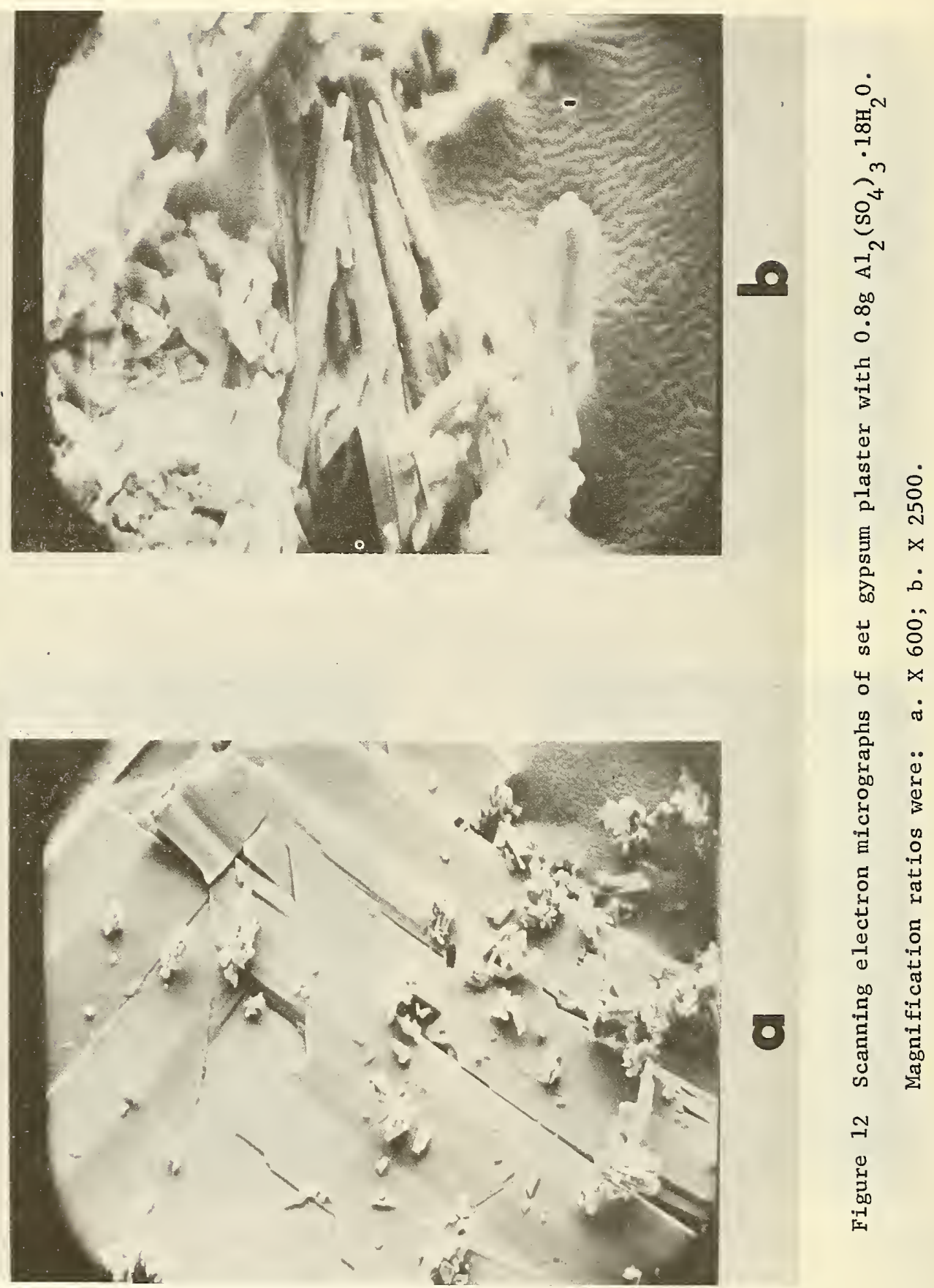
The addition of $\mathrm{Al}_{2}\left(\mathrm{SO}_{4}\right)_{3} \cdot 18 \mathrm{H}_{2} 0$ had some peculiar effects on the crystal habit of set gypsum plaster as shown ${ }^{2}$ in figure 12 (magnification ratio of 2500 for part a and 600 for part $\underline{b})$. While the crystals shown in figure $12 \mathrm{a}$ were rod-like, a considerable amount of much smaller crystals were also present. The most prominent crystal modifications are illustrated in figure 12b. These thin, flat crystals composed over ten percent of the total crystal area even though only $0.8 \mathrm{~g}$ of $\mathrm{Al}_{2}\left(\mathrm{SO}_{4}\right)_{3} \cdot 18 \mathrm{H}_{2} 0$ was mixed with $100 \mathrm{~g}$ of plaster of paris. The crystals of pure $\mathrm{Al}_{2}\left(\mathrm{SO}_{4}\right)_{3} \cdot 18 \mathrm{H}_{2} \mathrm{O}^{2}$ gave completely different micrographs.

\subsection{X-ray Powder Diffraction Patterns of Set Gypsum Plasters}

$X$-ray powder diffraction patterns were taken of samples of gypsum whose setting times were regulated by the following additives: $0.8 \mathrm{~g}, \mathrm{Al}_{2}\left(\mathrm{SO}_{4}\right)_{3} \cdot 18 \mathrm{H}_{2} 0 ; 0.2 \mathrm{~g}, \mathrm{Na}_{2} \mathrm{SO} / 0.1 \mathrm{~g}$, gelatin; $1.7 \mathrm{~g}, \mathrm{NH}_{4} \mathrm{C}_{2} \mathrm{H}_{3} \mathrm{O} ; 0.2 \mathrm{~g}$, succinic acid; and $0.2 \mathrm{~g},{ }^{4}$ tartarlc acid. The d-spacings of the calcium sulfate $e^{2}$ ihydrate patterns, for all the samples were the same as the spacings measured for $\mathrm{CaSO}_{4} \cdot 2 \mathrm{H}_{2} \mathrm{O}$. About 2 to 3 percent of unhydrated $\mathrm{CaSO}_{4}$ was detected in all of the patterns. Onty traces of unhydrated plaster of paris were observed in the $x-r a y$ patterns.

\section{Discussions}

\subsection{Setting and Hardening Mechanism of Gypsum Plaster}

It is well known that the setting and hardening processes of gypsum plaster involves the hydration of plaster of paris to form gypsum

$$
\mathrm{CaSO}_{4} \cdot 1 / 2 \mathrm{H}_{2} \mathrm{O}(\mathrm{s})+3 / 2 \mathrm{H}_{2} \mathrm{O}(1) \mathrm{CaSO}_{4} \cdot 2 \mathrm{H}_{2} \mathrm{O}(\mathrm{s})
$$

and the growth of interlocking crystals of gypsum. The hydration curve is sigmoidal (see figure 1) and can be broken into three segments: (1) an induction period or initial set during which little hydration taking place; (2) a segment in which hydration is rapidly taking place; and (3) the final set, the time during which the plaster of paris is completely hydrated. Segments (1) and (3) correspond to the two plateau regions in the curve. The kinetics of the setting and hardening reactions are controlled by the induction period.

Two theories have been proposed to account for the setting mechanism, the crystallization theory $[1,3,10]$ and the colloidal theory $[2,4,7]$. These theories basically differ in regards to their treatment of the induction period. According to the crystallization theory, the plaster of paris dissolves to form a highly supersaturated solution of calcium sulfate dehydrate and afterwards interlocking crystals of gypsum are separated from the solution. In the colloidal theory, the initial products are considered to have colloidal behavior. This material slowly convert into crystals of gypsum, with the conversion taking place before the induction period is completed. In the following discussion, the two theories will be examined in view of the results of the present study.

From calorimetric studies on gypsum plaster using set-regulating additives, Neville [7] concluded that a gel or adsorption complex was formed during the induction period. The role of cations on the setting rate was thought to indicate colloidal participation.

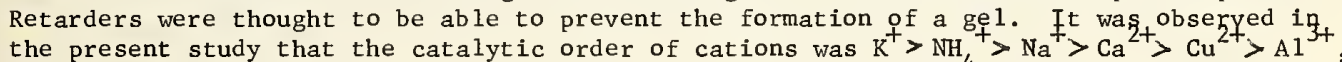
the present study that the catalytic order of cations was $\mathrm{K}>\mathrm{NH}_{4}>\mathrm{Na}>\mathrm{Ca}>\mathrm{Cu}^{2}$
with this series of decreasing activity being in close agreement with the order of increasing ionic potential. Howeyer, in the case of a purely colloidal phenomen the catalytic order should be $\mathrm{M}^{+3}>\mathrm{M}^{+2}>\mathrm{M}^{+}$. Ridge [9] considered the role of set-accelerators was to provide a greater density of effective nuclei, thereby leading to the accelerated rate of growth of gypsum crystals. While the results of the present study are consistent with this mechanism, the roles of the catalysts are apparently more complex than simply to increase the density of nuclei; otherwise, $\mathrm{CaSO}_{4} \cdot 2 \mathrm{H}_{2} \mathrm{O}$ should exert the largest catalytic effect. The small quantities of retarders used ${ }^{4}$ in the present study are probably not sufficient to coat the plaster of paris thoroughly, and, therefore, appear to hinder the hydration processes by other means. Possibly the set-retarders form adsorption or adduct complexes with effective sub-crystalline nuclei, in solution and thereby hinder the growth of seed crystals. 
Fischer reported [2] finding a small endothermic effect near $100^{\circ} \mathrm{C}$ in the differential thermograms of setting gypsum plasters (the hydration and crystallization processes were quenched at selected intervals by washing the paste with ethyl alcohol followed by acetone). This endothermic effect was observed within four minutes after mixing the plaster with water. Its magnitude increased with time so that after 45 minutes it was nearly as large as the endothermic effect of gypsum which has a $\mathrm{T}_{\text {peak }}$ of $197^{\circ} \mathrm{C}$. The presence of colloidal materials was considered as the source of the new endothermic effect. A similar study was carried out in the present work, however, the results (figure 11) were not in agreement with the findings of Fischer. An endotherm near $100^{\circ} \mathrm{C}$ was only detected 24 hours after mixing the plaster and water. If colloidal products were formed, they should be present in the initial stages of the setting of the setting of gypsum plaster, according to the colloidal theory. Possibly, the endothermic effect found near $100^{\circ} \mathrm{C}$ could be due to impurities or to the expulsion of excess water. A few endothermic effects was observed in the range of 100 to $120^{\circ} \mathrm{C}$ (table 3 ) for completely set plasters when set-regulator additives were used. Similar endothermic effects were not detected in the differential thermograms of the products resulting from the reaction of pure calcium sulfate hemihydrate with water or in the differential thermograms of $\mathrm{CaSO}, 2 \mathrm{H}_{2} 0[15]$. As shown in figures 10,11 , and 12 the set-regulators can modify the crystal habit of set gypsum plaster, causing differences in crystallinity, surface area, and porosity. Similar crystal modifications have been suggested as accounting for the differences in the differential thermograms of $\alpha$ and f-calcium sulfate hemihydrate [15], and possibly are associated with the endotherms of set gypsum plaster found in the $100^{\circ}$ to $120^{\circ} \mathrm{C}$ region.

Although it is difficult to unequivocally substantiate the crystallization theory, the results presented in this paper are in the most part consistent with this theory. However, it is felt that a reasonable modification to the theory would be the incorporation of the concept of solvated molecules of calcium sulfate hemihydrate; the molecules of the hemihydrate partly solvate in situ, thereby possessing a considerable amount of the character of calcium sulfate dihydrate. Then the molecules either completely solvate and thereby dissolve, or to a lesser extent they hydrate in situ. Evidence has been presented here and elsewhere [16] that such in situ processes are involved in the overall setting and hardening of gypsum plaster. Hansen has proposed [6] the formation of an absorption complex termed GA between hemihydrate molecules and water. This complex was thought to be closely akin to collidal partices. If GA was regarded as partly solvated calcium hemihydrate molecules, then the mechanism he proposed to account for the setting and hardening of gypsum plaster would be basically the same as the crystallization theory.

It is the opinion of the present author that the calcium sulfate molecules dissolve intact, essentially, with only a small degree of ionization taking place. This may account for the low solubilities of the molecules formed in the calcium sulfate-water system. Little information is presently available that elucidates the structure and molecular size of the dissolved molecules.

\subsection{Kinetic Relationships}

The kinetic equations used to treat kinetic relationships have been derived by Ridge [ 9 and 11] and Schiller [10] in the course of ascertaining the most reasonable mechanisms accounting for the setting and hardening of gypsum plasters. These relationships are evaluated in this section by using the data obtained in the present study.

Ridge developed the relationship:

$$
\Delta T=P e^{k t}
$$

where $\Delta T$ is the rise in temperature due to the hydration of plaster of paris, $P$ is a constant relating to the effective surface area of the dihydrate at the beginning of the reaction, $k$ is a constant proportional to the rate of diffusion of calcium sulfate to growing dihydrate crystals and the rate of incorporation of calcium sulfate in the dihydrate lattice, and $t$ is the time. In this relationship, $\Delta T$ is considered as a valid monitor of the progress of the hydration reaction and the equation is, of course, not valid when $\Delta T$ is zero. The main assumptions made in developing equation (1) are: the crystallization of gypsum is seeded; the growth of crystals is two dimensional; the surface area of the dihydrate is proportional to the mass; and only one reaction is taking place. 


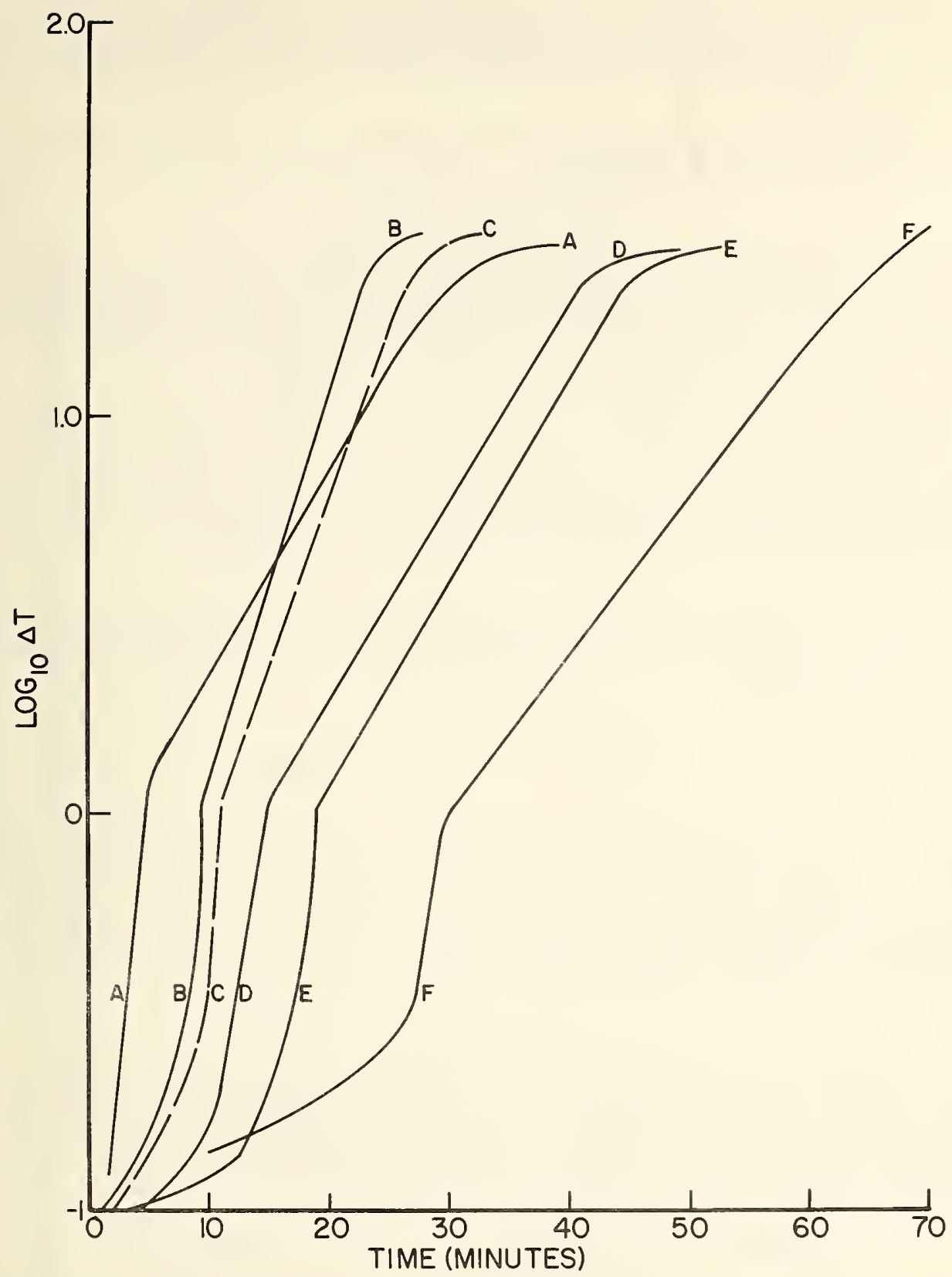

Figure $13 \log _{10} \Delta \mathrm{T}$ plotted versus time for the hydration of gypsum plaster regulated with accelerators: A. $3.0 \mathrm{~g} \mathrm{CaSO}_{4} \cdot 2 \mathrm{H}_{2} \mathrm{O} ; \mathrm{B} \cdot 0.5 \mathrm{~g} \mathrm{~K}_{2} \mathrm{SO}_{4} ;$ C. $0.4 \mathrm{~g} \mathrm{Na}_{2} \mathrm{SO}_{4} ;$ D. $1.0 \mathrm{~g}$ $\mathrm{CaSO}_{4} \cdot 2 \mathrm{H}_{2} \mathrm{O} ; \mathrm{E} .3 .3 \mathrm{~g} \mathrm{Al}_{2}\left(\mathrm{SO}_{4}\right)_{3} \cdot 18 \mathrm{H}_{2} \mathrm{O} ; \mathrm{F}$. no accelerator. 
If equation (1) held true when a plot of $\log _{10} \Delta T$ versus time should give a straight line. The experimental results are reproduced in figure 13. The equation should hold true especially in the early stages of the reactions. However, only when the induction periods were great ly reduced by the accelerators did the plotted data yield a straight line for the early hydration period.

Refinements of the above theory [11] to take into consideration latter portions of the hydration reaction led to the equation:

$$
\alpha=\mathrm{Pe}^{\mathrm{kt}} \text { for } \alpha<\alpha \text {, }
$$

wherex is the fraction of material hydrated $(\Delta T /$ total $\Delta T$ ), t and $k$ have the same significance as in equation (1), $P$ is the effective fraction of dihydrate present at the beginning of the reaction, and $\boldsymbol{\alpha}_{i}$ is the fraction of material hydrated at the stage when depletion of reactants and mutual interference of the growing crystals cause serious deviations from the conditions leading to the expotential rate of hydration. The value of $\alpha$, can be as high as 0.55 [17]. A plot of $\log _{10} \alpha$ versus time should give a straight line.

The plots of $\log _{10^{\alpha}}$ versus time for unregulated gypsum plaster and for plasters whose set times were regulated by the accelerators, $\mathrm{CaSO}_{4} \cdot 2 \mathrm{H}_{2} \mathrm{O}$ and $\mathrm{NaCl}$ are shown in figure 14 . The plot with $\mathrm{NaCl}$ as the accelerator should be dieferent than that for $\mathrm{CaSO}_{4} \cdot 2 \mathrm{H}_{2} 0$ because of a proposed difference in their catalytic functions [18]. This was not substantiated in the present study. Furthermore, the three plots did not yield straight lines. The refinements incorporated in equation (2) did not appear to greatly improve the agreement between the experimental data obtained in this study and the theory.

Schiller [10] has treated the hydration of plaster of paris using a model similar to that of Ridge's, i.e. a process of the hemihydrate going into solution and recrystallization of the calcium sulfate as the dihydrate. However, in Schiller's treatment recrystallization was not seeded and diffusion was not considered to be a rate determining factor. He developed the equation:

$$
t=B\left[\nu^{1 / 3}+1-(1-/ /)^{1 / 3}\right]
$$

where $Y^{\prime}=\frac{V_{D}}{V_{D}+V_{H}}$, with $V_{D}$ and $V_{H}$ being the volumes of the dihydrate and hemihydrate, respectively, and $\mathrm{B}$ is a constant, Schiller has, shown [10] that if this relationship holds, then a plot of time $t$ versus $\gamma^{1 / 3}+1-\left(1-y^{\prime}\right)^{1 / 3}$ should yield a straight line that should approach the origin if there is no induction period. Theoretically, $y$ can be obtained by dividing the temperature rise at any time by the total final temperature rise. The plots for unregulated gypsum plaster and for set regulated plaster, using $\mathrm{CaSO}_{4} \cdot 2 \mathrm{H}_{2} 0$ to eliminate the normal induction period, are reproduced in figure 15. The plotted line 2 s directed toward the origin when the induction period is eliminated; however, in both cases it is only near the later half of the hydration periods that the plots approximate straight lines.

The three kinetic equations evaluated above all give results that are in rough agreement with the experimental findings. None of the relationships hold well if an induction period is present. Apparently, the setting and hardening of gypsum plaster is a complex process not amenable to simple analysis as used in developing the kinetic equations. For example, the plots shown in figures 13,14, and 15 suggest that two reactions are taking place, whereas the kinetic equations were developed by assuming that only a single reaction is present.

\subsection{Variations in the Setting and Hardening Rates of Gypsum Plasters}

The rate at which gypsum plasters set and harden varies considerably between different plasters, and even can vary between samples of the same material. In the following, some factors which could cause the variations in setting and hardening rates will be briefly discussed.

The raw materials used in manufacturing gypsum plasters contain between 70 to $95 \%$ gypsum, with the major impurities being clays, limestone, and sedimentary rocks. The types 


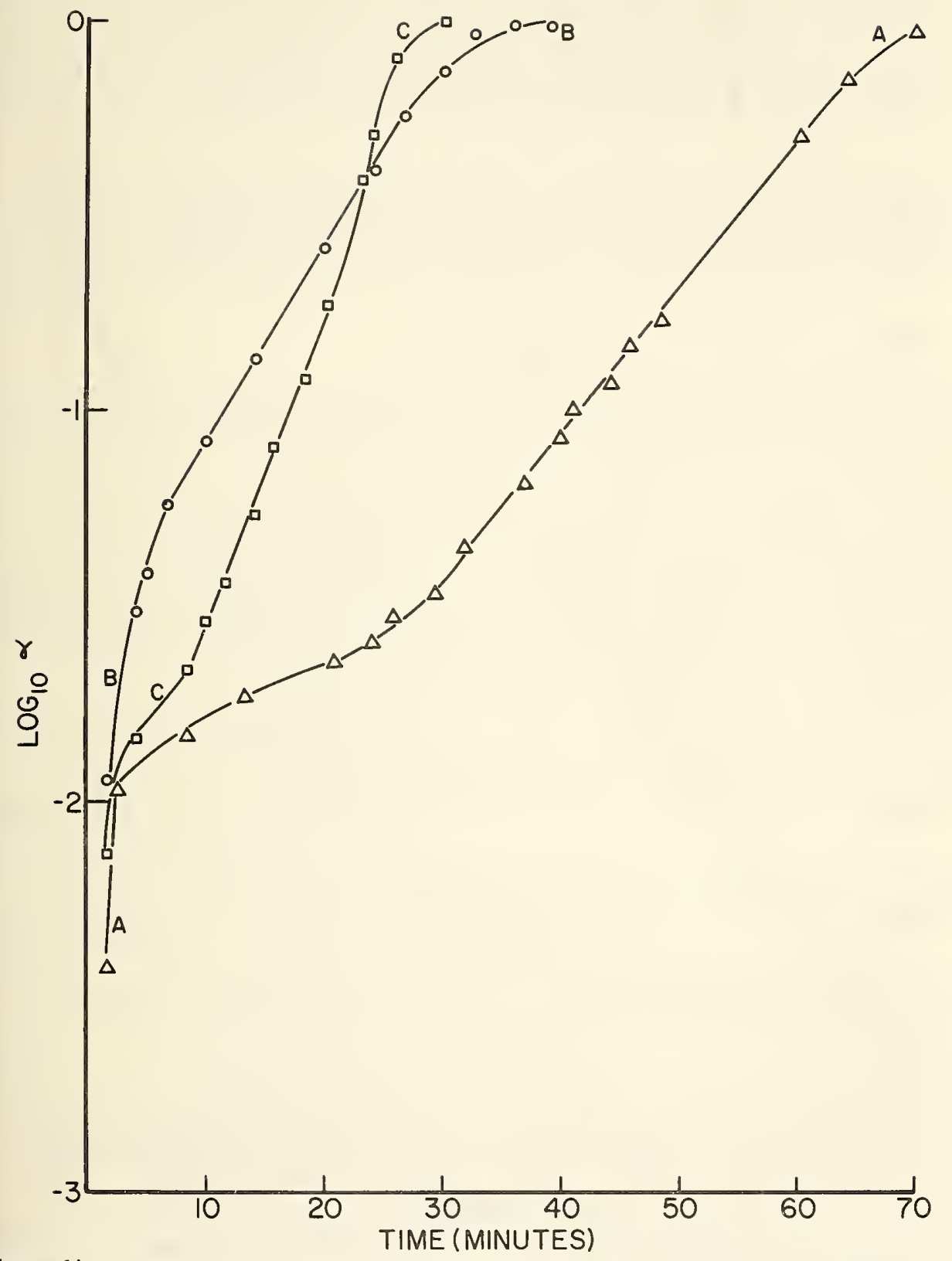

Figure $14 \log _{10} \alpha$ vs. time for the hydration of gypsum piaster: A. no additive; B. $3.0 \mathrm{~g}$ $\mathrm{CaSO}_{4} \cdot 2 \mathrm{H}_{2} \mathrm{O} ; \mathrm{C}$. $1.0 \mathrm{~g} \mathrm{NaCl}$. 


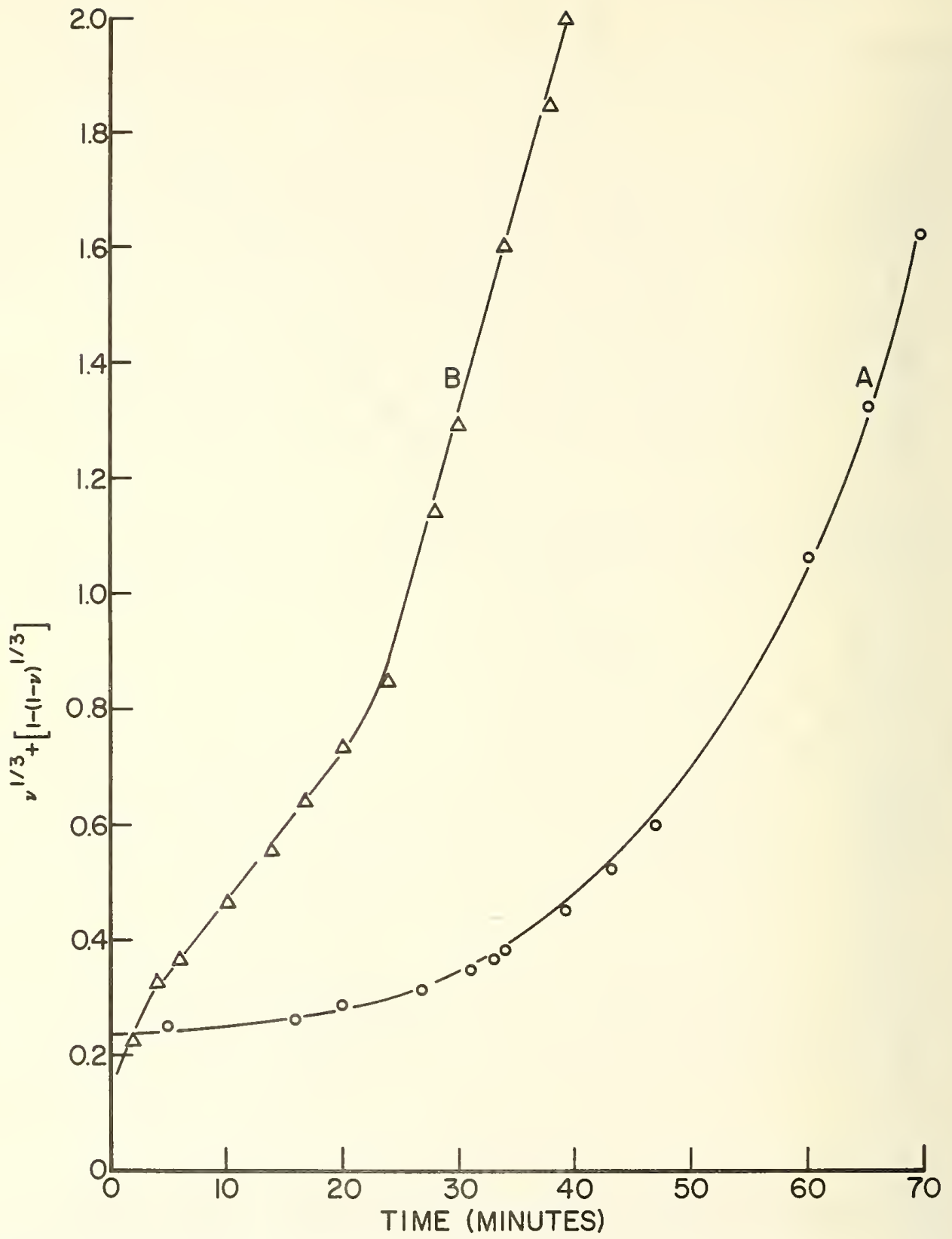

Figure 15 Plot of kinetic relationship derived by Schiller [10], versus time: A. no additive; $\mathrm{B}$. $3.0 \mathrm{~g} \mathrm{\textrm {CaSO } _ { 4 }} \cdot 2 \mathrm{H}_{2} \mathrm{O}$. 
and amounts of these impurities can be expected to vary in different deposits and to a lesser extent within the same deposit. Since these impurities probably have some influences on the setting parameters of plasters, it is not surprising that the setting and hardening rates vary between plasters from different sources. Setting and hardening rates of samples from the same manufacturer may not be consistent because the conditions under which the plaster of paris was prepared may not be precisely controlled. Production conditions such as heating time, maximum heating temperature, and relative humidity within the kettle can cause wide variations in the density of effective nuclei and in the amounts of $\mathrm{CaSO}_{4} \cdot 2 \mathrm{H}_{2} \mathrm{O}$ and $\alpha$-and $\beta$-CaSO 4 present in the plaster. The CaSO ${ }_{4} \cdot 2 \mathrm{H}_{2} \mathrm{O}$ does function as a set-accelerator, and if present in sufficient amounts, the induction period can be virtually eliminated ( $\operatorname{tab} 1 \mathrm{e} 1)$.

The temperature of mixing water can have an effect on the setting of gypsum plaster, as shown in figure 2 for temperatures from $0^{\circ}$ to $60^{\circ} \mathrm{C}$. The induction period and final set times decreased from $0^{\circ}$ to about $45^{\circ} \mathrm{C}$, and then increased. Gypsum plaster is normally cast at ambient temperatures between $12^{\circ}$ to $25^{\circ} \mathrm{C}$, which falls on a moderately descending portion of the curve corresponding to a slight increase in the setting rates with increasing temperature.

\section{Summary and Conclusions}

Gypsum plaster sets and hardens primarily through a dissolution and recrystallization process, which is generally consistent with the crystallization theory. However, some in situ hydration of the plaster takes place. It is felt that the crystallization theory should be modified to include the concept of solvated calcium sulfate hemihydrate molecules.

The role of set-accelerators is apparent ly to increase the density of seed crystals, which leads to a more rapid dissolution rate of the plaster and the subsequent crystallization of gypsum crystals. The cafion is more important than the anion, and the catalytic order follows the sequence $\mathrm{M}^{+}>\mathrm{M}^{2+}>\mathrm{M}^{3+}$. Retarders cannot inhibit the hydration of gypsum plasters merely by coating the molecules with a thin film because of the effectiveness of very small amounts of the retarders. Rather, retarders probably form adsorption or adduct complexes with dissolved nuclei, thereby hindering the growth of seed crystals.

Set-regulators can modify the differential thermograms, the macrocrystal shape and the size of set gypsum, although the $\mathrm{x}$-ray powder diffraction patterns of the set gypsum plasters are not changed.

No evidence for intermediate colloidal molecules in the hydration of calcium sulfate hemihydrate was found using differential thermal analysis, scanning electron microscopy, and set-regulating additives.

The kinetic equations developed by Ridge and Schiller do not hold well for the early portions of the hydration of gypsum plaster, especially when an induction period (the induction period is the rate determining step in the overall setting and hardening process of gypsum plaster) is present.

Temperature, impurities, and production conditions all have an influence on the setting parameters of gypsum plasters.

\section{Acknowledgment}

The author thanks Mrs. Peggy Baker for experimental assistance in the taking of the scanning electron micrographs. 
1. Ridge, M. J., Rev. Pure Appl. Chem., 10, 243 (1960), and reference contained therein.

2. Fischer, H. C., ASTM Bu11., No. 192, 43 (1953).

3. Le Chatelier, H., Trans. Faraday Soc., 14, 8 (1919).

4. Michaelis, W., Chem.-Ztg., 982 (1893); Kolloid-Zh., 12, 196 (1913).

5. Desch, C. H., Trans Faraday Soc., 14, 7 (1919).

6. Hansen, W. C., Mater. Res. Stand., 3, 359 (1963); ibid 4, 63 (1964).

7. Neville, H. A., J. Phys. Chem., 30, 1037 (1926).

8. Traube, J., Ko1loid-Zh., 25, 62 (1919).

9. Ridge, M. J., Aust. J. App1. Sci., 10, 218 (1959).

10. Schiller, K., J. Appl. Chem., 12, 135 (1962).

11. Ridge, M. J., Nature (London), 184, 47 (1959).

12. Householder, F. J., J. Amer. Ceram. Soc., 1, 578 (1918).

13. Kaempfe, F., Zem.-Kalk-Gips, 8, 77 (1953).

14. Worner, H. K., J, of Dent. Res., 23, 305 (1944).

15. Clifton, J. R., J. Res. Nat. Bur. Stand. (U.S.), 76A (Phys. and Chem.), 41 (1971).

16. Eipeltauer, E., Zem.-Kalk-Gips, 16, 9 (1963).

17. Ridge, M. J. and Surkevicius, H., J. App1. Chem., 12, 246 (1962).

18. Ridge, M. J. and Beretka, J. Rev. Pure and App1. Chem., 19, 17 (1969). 
FORM NBS-114A (1-71)

\begin{tabular}{|c|c|c|}
\hline $\begin{array}{l}\text { 1. PUBLICATION OR REPORT NO. } \\
\text { NBS - TN755 }\end{array}$ & $\begin{array}{l}\text { 2. Gov't Accession } \\
\text { No. }\end{array}$ & 3. Recipient's Accession No. \\
\hline \multicolumn{2}{|l|}{ 4. TIT LE AND SUBTITLE } & $\begin{array}{l}\text { 5. Publication Date } \\
\text { January } 1973\end{array}$ \\
\hline \multicolumn{2}{|c|}{ Some Aspects of the Setting and Hardening of Gypsum Plaster } & 6. Performing Organization Code \\
\hline \multicolumn{2}{|l|}{ James R. Clifton } & 8. Performing Organization \\
\hline \multirow{2}{*}{\multicolumn{2}{|c|}{$\begin{array}{l}\text { 9. PERF ORMING ORGANIZATION NAME AND ADDRESS } \\
\text { NATIONAL BUREAU OF ST AND ARDS } \\
\text { DEP ARTMENT OF COMMERCE } \\
\text { WASHINGTON, D.C. } 20234\end{array}$}} & 10. Project/Task/Work Unit No. \\
\hline & & 11. Contract/Grant No. \\
\hline \multirow{3}{*}{\multicolumn{2}{|c|}{ 12. Sponsoring Otganization Name and Address }} & $\begin{array}{l}\text { 13. Type of Report \& Period } \\
\text { Covered }\end{array}$ \\
\hline & & Final \\
\hline & & 14. Sponsoring Agency Code \\
\hline
\end{tabular}

\section{SUPPLEMENT ARY NOTES}

16. ABSTRACT (A 200-word or less factual summary of most significant information. If document includes a significant bibliography or literature survey, mention it here.)

The mechanisms by which gypsum plaster sets and hardens have been investigated and the results generally are consistent with the crystaliization theory. No evidence for the presence of colloidal intermediates has been found. The crystallization theory is modified to include, as an intermediate species, solvated calcium sulfate hemihydrate molecules. Evidence is presented that supports the belief that more than one reaction is responsible for the setting and hardening of gypsum plaster.

The roles of accelerators and retarders have been studied by calorimetric, differential thermal analysis, and scanning electron microscopic techniques. The cation is more effective than the anion in accelerating the setting and hardening of gypsum plasters; the catalytic order follows the sequence $\mathrm{M}^{+} \mathrm{M}^{2+} \mathrm{M}^{+}$. Small amounts of retarders can severely retard the setting and hardening processes.

Influences of temperature, impurities, and production conditions on the setting rates of gypsum plasters are discussed.

17. KEY WORDS (Alphabetical order, separated by semicolons) Colloidal theory; crysta11ization theory; gypsum; hydration; induction period; plaster of paris; setting mechanisms

18. AVAILABILITY STATEMENT

X UNLIMITED.

FOR OFFICIAL DISTRIBUTION. DO NOT RELEASE TO NTIS.

\begin{tabular}{|l|c|}
$\begin{array}{l}\text { 19. SECURITY CL,ASS } \\
\text { (THIS REPORT) }\end{array}$ & $\begin{array}{c}\text { 21. NO. OF PAGES } \\
\text { UNCL ASSIFIED }\end{array}$ \\
\hline $\begin{array}{l}\text { 20. SECURITY CLASS } \\
\text { (THIS PAGE) }\end{array}$ & $\begin{array}{l}\text { 22. Price } \\
\text { \$.55 Domestic Postpaid } \\
\text { \$.40 GPO Bookstore }\end{array}$ \\
\hline & UNCL ASSIFIED \\
\hline
\end{tabular}





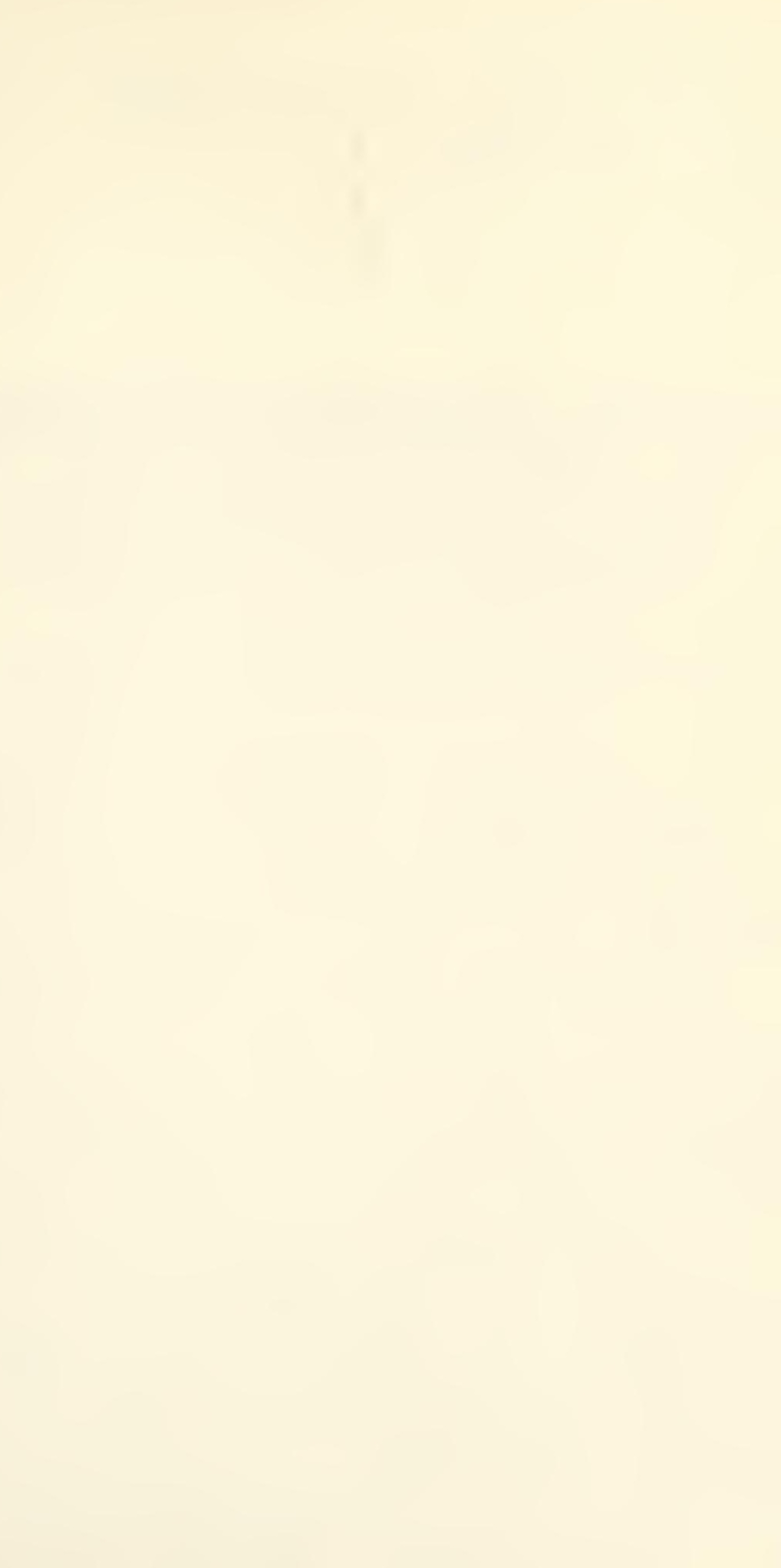

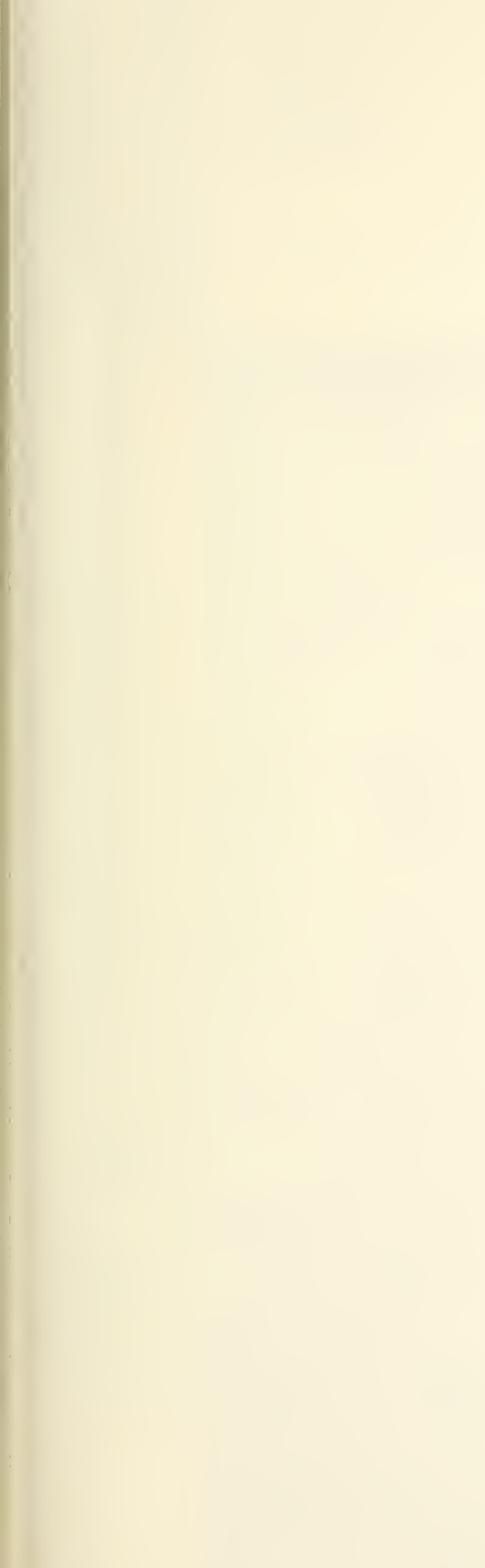


U.S. DEPARTMENT OF COMMERCE

National Bureau of Standards

Washington, D.C. 20234

DFFICIAL BUSINESS

Penalty for Private Use, $\$ 300$
POSTAGE AND FEES PAID U.S. OEPARTMENT OF COMMERCE 215

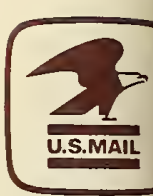

